\title{
EFFECTS OF WATER IN SYNTHETIC LUBRICANT SYSTEMS AND \\ CLATHRATE FORMATION: A LITERATURE SEARCH AND REVIEW
}

Final Report: August 14, 2000 to August 8, 2001

Date Published -August 8, 2001

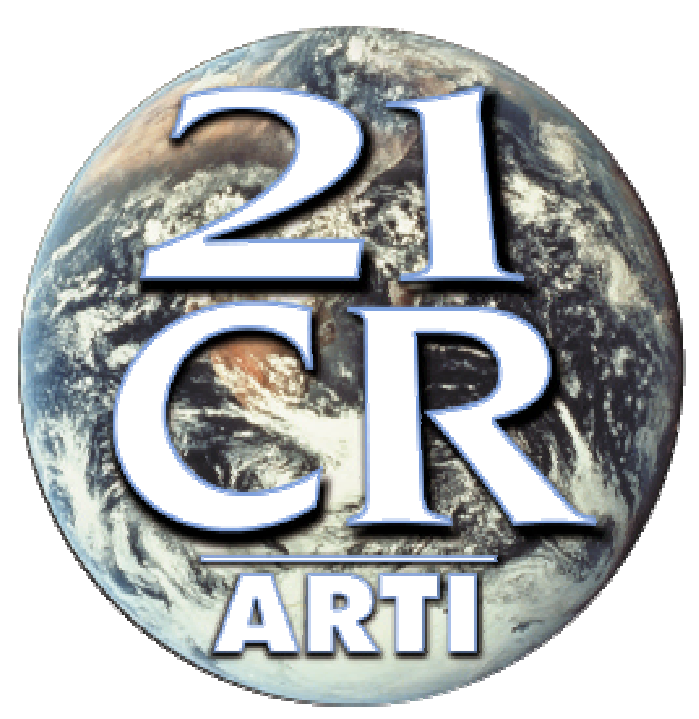

Ngoc Dung T. Rohatgi

SPAUSCHUS ASSOCIATES, INC.

178 West Athens Street

Winder, Georgia, 30680

Prepared for the

AIR-CONDITIONING AND REFRIGERATION TECHNOLOGY INSTITUTE 4301 N. Fairfax Drive, Suite 425, Arlington, Virginia 22203

Distribution A - Approved for public release; further dissemination unlimited. 


\section{DISCLAIMER}

This report was prepared as an account of work sponsored by the Air-Conditioning and Refrigeration Technology Institute (ARTI) under its "HVAC\&R Research for the $21^{\text {st }}$ Century" (21-CR) program. Neither ARTI, the financial supporters of the 21-CR program, or any agency thereof, nor any of their employees, contractors, subcontractors or employees thereof - makes any warranty, expressed or implied; assumes any legal liability or responsibility for the accuracy, completeness, any third party's use of, or the results of such use of any information, apparatus, product, or process disclosed in this report; or represents that its use would not infringe privately owned rights. Reference herein to any specific commercial product, process, or service by trade name, trademark, manufacturer, or otherwise, does not necessarily constitute nor imply its endorsement, recommendation, or favoring by ARTI, its sponsors, or any agency thereof or their contractors or subcontractors. The views and opinions of authors expressed herein do not necessarily state or reflect those of ARTI, the 21-CR program sponsors, or any agency thereof.

Funding for the 21-CR program provided by (listed in order of support magnitude):

- U.S. Department of Energy (DOE Cooperative Agreement No. DE-FC05-99OR22674)

- Air-Conditioning \& Refrigeration Institute (ARI)

- Copper Development Association (CDA)

- New York State Energy Research and Development Authority (NYSERDA)

- Refrigeration Service Engineers Society (RSES)

- Heating, Refrigeration Air-Conditioning Institute of Canada (HRAI)

Available to the public from

U.S. Department of Commerce

National Technical Information Service

5285 Port Royal Road

Springfield, VA 22161

(703) 487-4650

Available to U.S. Department of Energy and its contractors in paper from

U.S. Department of Energy

Office of Scientific and Technical Information

P.O. Box 62

Oak Ridge, TN 37831

(423) 576-8401 


\section{EFFECTS OF WATER IN SYNTHETIC LUBRICANT SYSTEMS AND CLATHRATE FORMATION: A LITERATURE SEARCH AND REVIEW}

Final Report: August 14, 2000 to August 8, 2001

Date Published -August 8, 2001

Ngoc Dung T. Rohatgi

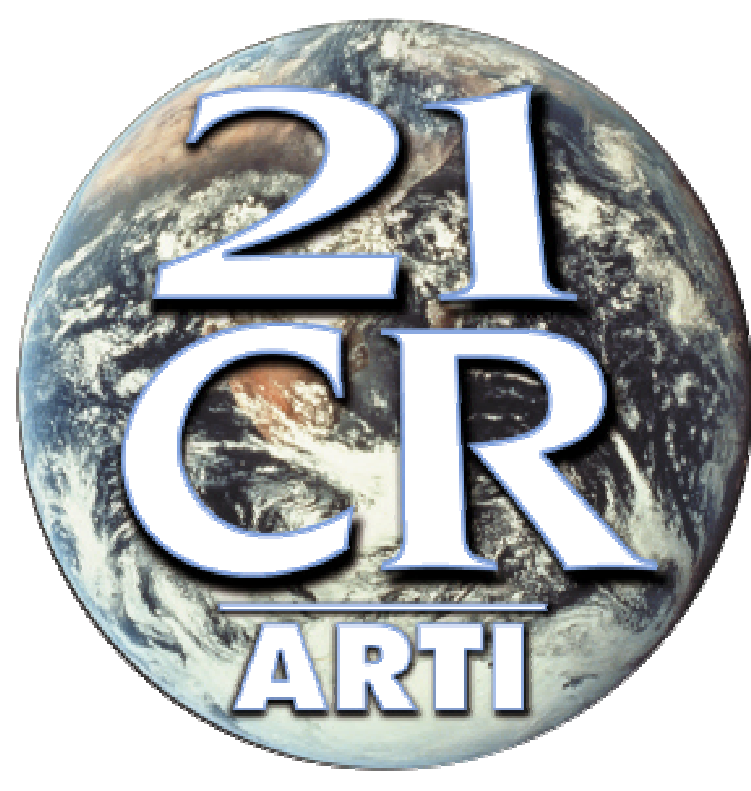

Prepared for the

AIR-CONDITIONING AND REFRIGERATION TECHNOLOGY INSTITUTE

Under ARTI 21-CR Program Contract Number 610-50035-01 


\section{EXECUTIVE SUMMARY}

Moisture is a universal contaminant of refrigeration systems, and a scientific understanding of the effects of water in these systems is needed for their proper design, efficient operation, and reliable service. The effects of water on chlorofluorocarbons and mineral oil have been extensively studied. In these non-polar systems with low solubility for water, moisture levels are usually controlled to twenty five parts per million or less to avoid free water and the associated corrosion of metals, compatibility problems with polymeric materials, and possible ice formation in expansion valves, capillary tubes, or evaporators. The phase-out of chlorofluorocarbon/mineral oil systems and the introduction of alternative hydrofluorocarbon (HFC) refrigerants and their compatible synthetic lubricants have once more raised concerns about the effects of water on the stability of refrigeration systems. The HFC/synthetic lubricant systems are polar and have good solubility for moisture, thus present reduced risk of free water with its associated problems. The current common practice of equipment manufacturers is to allow moisture levels of 50-100 parts per million (ppm) or less in new equipment with HFC and synthetic lubricants. However, service practices are not well controlled and may lead to high levels of water in the refrigeration system. Because of the different types of synthetic lubricants and system designs encountered in the refrigeration and airconditioning industry, initial investigations into the effects of excess water with the HFC/synthetic lubricant working fluids are limited, proprietary, or of a screening nature. There has not been a reported in-depth study of the effects of moisture on the long-term stability of the HFC/synthetic lubricant systems. Such a study would assist the equipment manufacturers in defining allowable maximum limits of water concentration for 
satisfactory long-term operation of the HFC/synthetic lubricant systems, and evaluating potential difficulties associated with the presence of excessive water.

Under ARTI 21-CR Project 610-50035-01, Spauschus Associates, Inc. has compiled and critically evaluated the current state of knowledge of the effects of water on the stability of $\mathrm{HFC} /$ synthetic lubricant systems to identify key areas requiring further investigation. An extensive literature search was conducted and a confidential survey was prepared and sent to compressor, lubricant, desiccant and filter-drier manufacturers to determine the industry specifications on the amount of water allowable in the HFC/synthetic lubricant systems. Following are highlights from the extensive literature review and analysis of the survey:

- Clathrate hydrates, first discovered in 1810 , are solid solutions formed when water molecules are linked through hydrogen bonding creating cavities that can enclose various guest molecules also know as hydrate formers. The formation, nucleation, growth, decomposition, structures, properties, and thermodynamic phase equilibria have been reported for a number of hydrate formers, including HFC refrigerants such as R-32, R-125, R-134a, R-407C and R-410A. Four methods for preventing the formation of clathrate hydrates were cited, including drying the gas, heating it to a temperature above the equilibrium formation temperature at a given pressure, reducing the gas pressure to below the hydrate formation pressure at a given temperature, or injecting inhibiting substances. 
- Polyolester (POE) lubricants hydrolyzed in the presence of water while polyvinylethers (PVE) do not. Hydrolysis activity of POE was more frequently acidcatalyzed than base-catalyzed and tended to increase with high water content and high residual carboxylic acids. The hydrolysis reaction rate constants typically showed temperature dependence consistent with an activated process following the Arrhenius equation. Hydrolytic stability of POE was shown to improve with hindered POE, and with the presence of acid catcher additives and molecular sieve desiccant. In general, under lubricated conditions, water vapor can modify the adsorption of long-chain fatty acids that act as boundary lubricants, thus influencing friction and wear. Water can also affect the chemistry of protective film formation by oxygen. However, depending on the lubricants tested and the conditions of the tests, the effects can be either positive or negative. A positive effect corresponds to a decrease in wear with increasing water content while a negative effect corresponds to an increase in wear with increasing water content.

- In the study of the distribution of moisture between R-134a, polyalkylene glycol (PAG) and desiccant, it was concluded that at equilibrium, some moisture from the PAG redistributed between the refrigerant and the desiccant with the larger fraction going to the desiccant. In addition, the study of moisture dynamics showed that under steady state operation, moisture is distributed between the refrigerant and the lubricant after twenty-four hours. The amount of moisture varies according to the total system moisture and, if desiccant is present, on the degree of desiccant saturation. It was also determined that approximately fifty to sixty percent of the moisture injected into an air-conditioning system remains in the refrigerant and the 
rest mixes with the compressor oil. In an automotive air-conditioning system using $\mathrm{R}-134 \mathrm{a}$, it was discovered that ice would form in the refrigerating cycle at $0{ }^{\circ} \mathrm{C}$ evaporating temperature when the water content in the vapor refrigerant on the lowpressure side is more than $350 \mathrm{ppm}$.

- The presence of moisture was observed to cause the embrittlement of polyethylene terephthalate and the hydrolysis of polyester materials. On the positive side, water was shown to reduce the effect of amine additives on fluoroelastomer rubbers. The reactions of water with refrigerants or the hydrolysis of organic solvents and lubricants have been shown to cause formicary and large-pit corrosion in copper tubes, as well as copper plating and sludge formation in refrigeration systems. Moreover, studies of blockage of capillary tubes showed that blockage is low in dry systems, but increases rapidly in the presence of water or when the system is doped with carboxylic acid.

- The responses from the twenty-four companies that participated in the survey suggested that the water concentrations specified and expected for different refrigerant/lubricant systems vary depending on the products, their capacities and applications, and also on the companies. Among the problems that would most likely result from the presence of high moisture level in the refrigeration systems, lubricant breakdown is of greatest concern, followed by acid formation, compressor failure and expansion valve sticking. Elastomeric seal failure and sticking of suction valve cause fewer concerns. 
The following research topics are suggested for future investigation, in the order of their importance, practicality and ease of implementation:

1. The air-conditioning and refrigeration industry needs to measure and record the water content and total acid number of the lubricant of newly installed systems as well as operating systems that are shutdown for service or repair. The reason for the shutdown and repair needs to be documented. A database can then be established to correlate water content in systems with type of breakdown or problems encountered. This research project is easy to implement and has practical application, because the database, combined with detailed studies on the distribution of water in refrigeration and air-conditioning systems, would help the industry in setting meaningful limits on the allowable water content in newly installed equipment, either field-erected or factory-sealed.

2. Along with the database, detailed studies on the distribution of water in refrigeration and air-conditioning systems should be conducted to pinpoint problem areas associated with free water, and to help in the formulation and implementation of effective solutions to these problems.

3. Although formicary corrosion is a real phenomenon leading to copper tube failures, it is less well known than other forms of corrosion. Formicary corrosion has been successfully replicated in the laboratory, but research is still needed to validate the current theories and mechanisms for this type of corrosion. Studies are needed to determine the rate of pit formation and propagation, the conditions of temperature, 
water content, acid content, and oxygen content needed to initiate the corrosion process. Corrosion inhibitors need to be developed and evaluated.

4. Although studies have been conducted on a number of hydrate formers including hydrofluorocarbon refrigerants, the conditions for formation and decomposition of clathrate hydrates of other alternative refrigerants under consideration for use in refrigeration and air-conditioning systems and water should be determined to avoid possible problems associated with tube plugging. These alternative refrigerants may include R-23, R-41, R-116, R-125, R-143a, and refrigerant blends such as R-404A and R-507C.

5. The mechanism by which water facilitates or hinders lubrication is not known and needs to be studied and characterized in order to formulate more effective lubricants and lubricant additives. 


\section{TABLE OF CONTENTS}

EXECUTIVE SUMMARY.............................................................

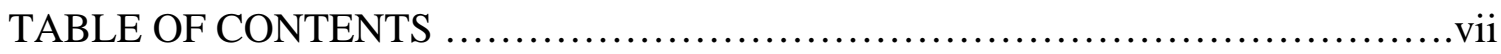

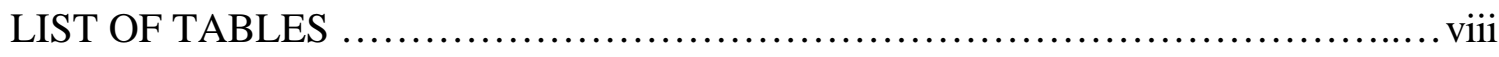

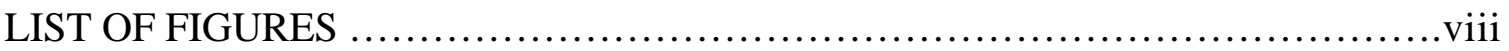

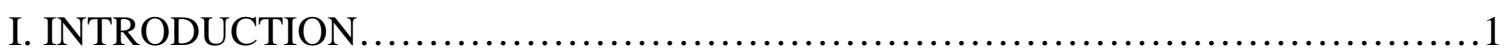

\section{CLATHRATE FORMATION AND DECOMPOSITION IN HFC-WATER}

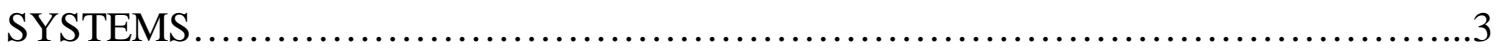

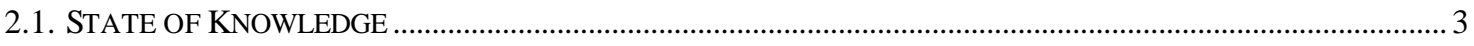

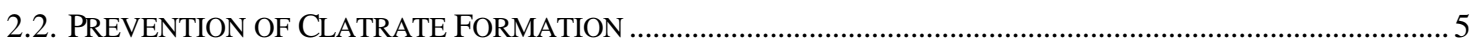

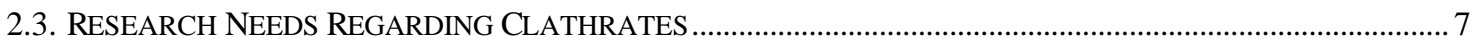

III. WATER IN REFRIGERANT AND LUBRICANT SYSTEMS ...................9

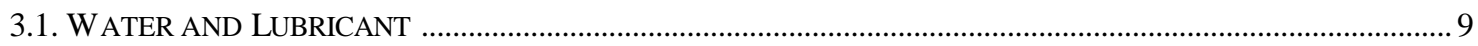

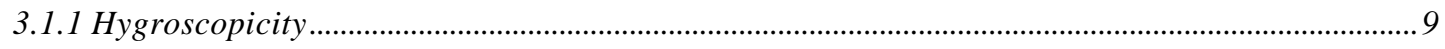

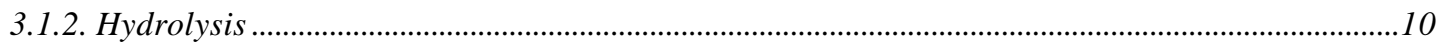

3.1.3. Effect of Water on Tribological Properties of Lubricants.................................................................11

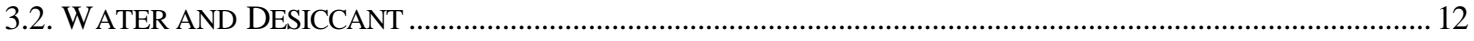

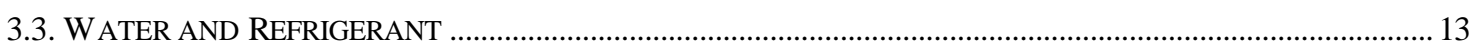

3.4. PARTITIONING OF WATER BETWEEN REFRIGERANT, LUBRICANT AND DESICCANT ............................... 14

3.5. RESEARCH NEEDS REGARDING W ATER IN REFRIGERANT/LUBRICANT SYSTEMS .................................. 16 


\section{EFFECT OF WATER ON MATERIALS OF CONSTRUCTION IN}

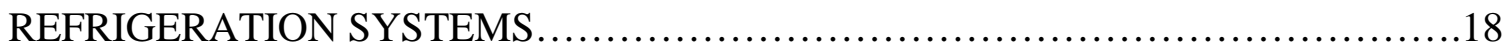

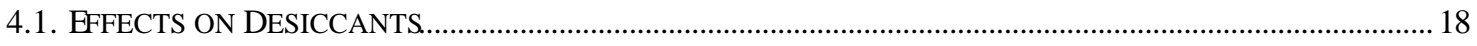

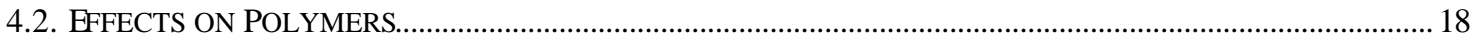

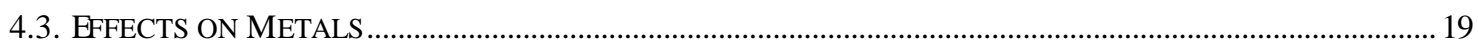

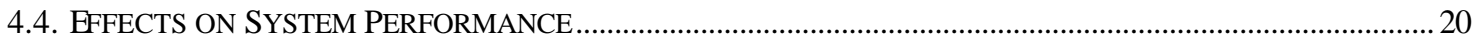

4.5. RESEARCH NEEDS REGARDING THE EFFECT OF W ATER ON MATERIALS OF CONSTRUCTION ............... 21

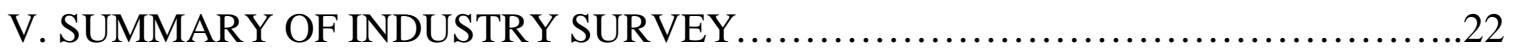

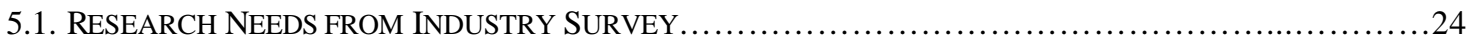

VI. CONCLUSIONS ....................................................... 30

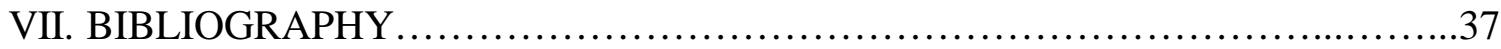

\section{LIST OF TABLES}

TABLE 3.1. SumMARY OF EXPERIMENTAL RESUltS FROM SHEIRETOV ET AL.............13

TABlE 5.1. CONFIDENTIAL SURVEY: EFFECTS OF WATER IN HVAC S YSTEMS............25

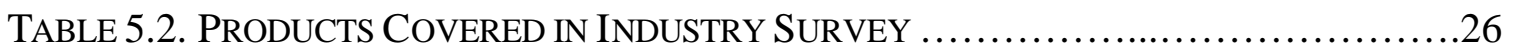

TABLE 5.3. REFRIGERANTS AND LUBRICANTS REPORTED IN USE IN SURVEY.............27

TABLE 5.4. REFRIGERANT/LUBRICANT USAGE...................................27

TABle 5.5. SPECIFIED, EXPECTED AND MEASURED WATER CONTENT.....................28

Table 5.6. Possible Problems Caused by High Water Contents...................29

\section{LIST OF FIGURES}

FIGURE 5.1. REFRIGERANT/LUBRICANT USAGE..................................28 


\section{EFFECTS OF WATER IN SYNTHETIC LUBRICANT SYSTEMS AND CLATHRATE FORMATION: A LITERATURE SEARCH AND REVIEW}

\section{INTRODUCTION}

Moisture is a universal contaminant of refrigeration systems and a scientific understanding of the effects of water in these systems is needed for their proper design, efficient operation, and reliable service. The effects of water on chlorofluorocarbons (CFC) and mineral oil have been extensively studied (Walker 1962; Borah 1955; Nippon Reito Kyokai 1981). In these non-polar systems with low solubility for water, moisture levels are usually controlled to twenty five parts per million or less to avoid free water and the associated corrosion of metals, compatibility problems with polymeric materials, and possible ice formation in expansion valves, capillary tubes, or evaporators. The phase-out of $\mathrm{CFC} /$ mineral oil systems and the introduction of alternative hydrofluorocarbon (HFC) refrigerants and their compatible synthetic lubricants have once more raised concerns about the effects of water on the stability of refrigeration systems. The HFC/synthetic lubricant systems are polar and have good solubility for

moisture, thus present reduced risk of free water with its associated problems. The current common practice of equipment manufacturers is to allow moisture levels of 50100 parts per million (ppm) or less in new equipment with HFC and synthetic lubricants. However, service practices are not well controlled and may lead to high levels of water in the refrigeration system. Because of the different types of synthetic lubricants and system designs encountered in the refrigeration and air-conditioning industry, initial investigations into the effects of excess water with the HFC/synthetic lubricant working 
fluids are limited, proprietary, or of a screening nature. There has not been a reported indepth study of the effects of moisture on the long-term stability of the HFC/synthetic lubricant systems. Such a study would assist the equipment manufacturers in defining allowable maximum limits of water concentration for satisfactory long-term operation of the HFC/synthetic lubricant systems, and evaluating potential difficulties associated with the presence of excessive water.

Under ARTI 21-CR Project 610-50035-01, Spauschus Associates, Inc. has compiled and critically evaluated the current state of knowledge of the effects of water on the stability of HFC/synthetic lubricant systems to identify key areas requiring further investigation. An extensive literature search was conducted. Databases such as Engineering Index (ENGI), Science Abstracts (INSPEC), National Technical Information Service (NTIS), Applied Science and Technology Abstracts Citation, Academic Press Journals, IBM Patent server, Science citation index, Current Contents and Ferret (ARTI Refrigerant Database) were accessed. A confidential survey was prepared and sent to compressor, lubricant, desiccant and filter-drier manufacturers to determine the industry specifications on the amount of water allowable in the HFC/synthetic lubricant systems. From the extensive literature review and the data collected from the survey, critical research needs were identified, which would fill any existing gap in the scientific understanding of the effects of water in HFC/synthetic lubricant systems. 


\section{CLATHRATE FORMATION AND DECOMPOSITION IN HFC-WATER SYSTEMS}

\subsection{STATE OF KNOWLEDGE}

Clathrate hydrates, first discovered in 1810 , are solid solutions formed when water molecules, linked through hydrogen bonding, create cavities that can be occupied by various guest molecules also known as hydrate formers. Englezos (1993) reviewed the formation, structures and properties of clathrade hydrates, described their phase equilibria and thermodynamic models, and discussed their nucleation, growth and decomposition. If the hydrate former is only sparingly soluble in liquid water, the hydrate preferentially forms at the water/hydrate-former-interface, replacing the interface with a polycrystalline hydrate film. Sugaya and Mori (1996) visually estimated the film thickness of R-134a clathrate hydrate to be around 10 microns (: m) or less, while Ohmura, Kashiwazaki and Mori (2000) measured the thickness of clathrate-hydrate of liquid R-134a and water with a laser interferometer. Ohmura, Shigetomi and Mori (1999) studied the thick hydrate films growing along the surface of R-141b drops immersed in liquid water at a relatively small subcooling, and estimated the film thickness to be 0.1-0.2 millimeters. Similarly, two discrete hydrate crusts grow along the liquid-liquid interface when a drop of HCFC$141 \mathrm{~b}$ is formed from a single nozzle into a water stream in favorable thermodynamic conditions (Kato, Iida and Mori 2000). Using high-speed videography, Mori (1996) observed a solid clathrate hydrate phase form at the fluorocarbon/water interface and 
encapsulate a drop of R-134a in a water pool. On the microscopic level, Sloan et al. (1998) described the first Raman spectra for the formation of both uninhibited and inhibited methane hydrates with time. This method has the potential to provide a microscopic-based kinetics model.

Clathrate compounds have been found under the evaporating pressure condition of a refrigeration unit using R-407C and R-410A (Matsuo, Tagashira and Yoshida 1996). The critical decomposition temperature of the clathrate between HFC-32 and water was reported as $17.6^{\circ} \mathrm{C}$ (Davidson 1973), and that of the clathrate between HFC-134a and water was $10{ }^{\circ} \mathrm{C}$ (Oowa et al. 1990). The critical decomposition temperature is the maximum temperature for the existence of the clathrate. Tanii et al. (1997) recorded the critical decomposition temperature of HCFC-141b clathrate as $8.5^{\circ} \mathrm{C}$ and showed that the addition of $0.05 \%$ by weight of surfactant increased the clathrate formation rate while the addition of ethylene glycol lowered the clathrate formation/decomposition temperature. Akiya et al. (1997, 1999) studied the formation conditions of clathrates between HFC refrigerants and water. Mixtures of refrigerant and deionized water were first cooled until clathrate formation was observed. The temperature of the mixtures was then raised until the clathrate disappeared. Equilibrium pressures were recorded at selected temperatures during the cooling and heating cycles. Pressure $(\mathrm{P})$ versus temperature $(\mathrm{T})$ curves before the formation of the clathrate were condensation curves. $\mathrm{P}$ versus $\mathrm{T}$ curves between clathrate formation and clathrate decomposition were called clathrate formation curves. 
Condensation and clathrate formation curves, which were linear with a logarithmic pressure scale and linear temperature scale, were obtained for each of the following refrigerants and water: HFC-32, HFC-125, HFC-134a, and refrigerant blends R-407C and R-410A. The critical decomposition temperature $\mathrm{T}_{\mathrm{c}}$ and the critical decomposition pressure $\mathrm{P}_{c}$ were obtained from the intersection of the condensation line and clathrate formation line. From their studies, the authors concluded that R-407C and R-410A form clathrate compounds with water under the evaporating temperature condition in the refrigeration cycle of air-conditioners and heat pumps, operating below $14{ }^{\circ} \mathrm{C}$. Ethirajan and Najafi (1993) described a cool energy storage system that operated in a "directcharge" mode to form solid refrigerant R-134a clathrate as its storage medium. A mathematical model was formulated to predict the temperature field within the storage tank during the charging operation. Another cool storage system using R-141b was described by Akiya et al. (1991). The formation of hydrate layers in pipes was observed by Dorstewitz and Mewes (1994). They noted that a plug started forming on the pipe wall where the interface between water and R-134a was located, then a hydrate layer covered the whole perimeter of the wall and grew radially towards the center of the pipe. The thickness of the hydrate layer can be related to the measured heat transfer resistances and measured pressure losses.

\subsection{PREVENTION OF ClATRATE FORMATION}

Englezos (1993) cited four methods for preventing the formation of clathrates, including drying the gas, heating it to a temperature above the equilibrium hydrate 
formation temperature at a given pressure, reducing the gas pressure to below the hydrate formation pressure at a given temperature, or injecting inhibiting substances. Known clathrate inhibitors include methanol, ethanol, ethylene glycol, diethylene glycol, butanone, acetone, or electrolytes such as $\mathrm{NaCl}, \mathrm{KCl}, \mathrm{CaCl}$, and $\mathrm{NH}_{3}$ (Holder, Zetts and Pradhan 1988; Gubbins 1993; Koga, Tanaka and Nakamishi 1994). Becke, Kessel and Rahimian (1994) determined that liquid hydrocarbons add to the effects of inhibitors in lowering the critical decomposition temperatures of gas hydrates. In addition to alcohols, glycols, and electrolytes, which are known as thermodynamic inhibitors, water-soluble polymers are found to have inhibiting potential (Englezos 1992; Lederhos et al. 1996). These inhibitors, also called kinetic inhibitors, generally are effective at less than one weight percent in the aqueous phase whereas methanol is used between 10 and $60 \%$. They work by increasing the time delay in the formation of clathrate hydrates. Because of the high degree order required to arrange the water molecules around the guest molecules, the formation of hydrates requires some time even under thermodynamically favorable conditions (Notz et al. 1996). King et al. (2000) and Hutter, King and Lin (2000) used small-angle neutron scattering to characterize the mechanism for kinetic hydrate inhibition of nonionic water soluble polymers such as poly(ethylene oxide), poly(N-vinyl-2-pyrollidone), poly(N-vinyl-2-caprolactam) and $\mathrm{N}$-methyl, $\mathrm{N}$ vinylacetamide/N-vinyl-2-caprolactam copolymer. They discovered that a principle mechanism of hydrate kinetic suppression involves surface adsorption onto the growing crystals accompanied by slowing of the growth. Another mechanism of inhibition 
involves an association between the hydrate-forming components and the polymer, which might act to alter the nucleation behavior, as suggested by Lederhos et al. (1996).

\subsection{RESEARCH NEEDS REGARDING CLATHRATES}

- The study of the formation conditions of clathrates between single component HFC refrigerants, such as R-23 (trifluoromethane), R-41 (fluoromethane), R-116 (hexafluoroethane), R-125 (pentafluoroethane), R-143a (1,1,1-trifluoroethane), and water should be continued.

- Based on the research of Akiya et al. (1997, 1999), when $\mathrm{T}_{c}$ is plotted on linear scale versus $P_{c}$ on logarithmic scale, the point representing $R-410 A$ is located on the straight line connecting those representing R-32 and R-125. Similarly, the critical clathrate decomposition point of R-407C is close to the straight line connecting those of R-410A and R-134a. These results would suggest that it is possible to determine the clathrate decomposition conditions of a blend of HFC refrigerants from the data of its individual components. This phenomenon should be investigated for various refrigerant blends, such as R-404 A (which is 44\% R-125, 52\% R-143a, and 4\% R134a) and R-507 C (which is 50\% R-125 and 50\% R-143a).

- There is a need to research and develop new inhibitors to prevent clathrate formation, agglomeration or deposition, because the currently used thermodynamic inhibitors have to be used in large quantities and thus tend to be costly (Pakulski 1998; Rabeony et al. 1998; Colle et al. 2000), while the current kinetic inhibitors are either not very 
effective or can only be applied under limited conditions (Klug and Holtrup 2001; Namba et al. 2001).

- In situ measurement techniques, such as the laser interferometer, axial flow viewing and photography, or Raman Spectra should be developed and applied in the measurement of clathrate film thickness at various locations in the refrigeration system where the thermodynamic conditions are conducive to the formation of clathrate hydrates. 


\section{WATER IN REFRIGERANT AND LUBRICANT SYSTEMS}

\subsection{WATER AND LUBRICANT}

\subsubsection{Hygroscopicity}

In describing the water absorption of synthetic lubricants, Echin, Novosartov and Popova (1981) stated that hygroscopicity of oils based on esters increased with increasing relative humidity of the air (according to Henry's law) and with increasing temperature. For the diesters and pentaerythritol esters, the water solubility is directly proportional to temperature. In addition, pentaerythritol esters that have higher hydroxyl number were seen to absorb more water. Kussi (1985) studied the water absorption of various synthetic polyether lubricants (also known as polyalkylene glycol or PAG). He reported that water absorption is dependent on the content of ethylene oxide in the polyether molecule, the degree of polymerization, and the temperature. Pure, higher-molecular weight propylene oxide polyethers absorb little water (less than $5 \%$ water based on lubricant weight), while polyethers with a small proportion of ethylene oxide content absorb more water (35\% or more). The capacity of these polymers to absorb water decreases with increasing molecular weight. Polyethers with an ethylene oxide content greater than $40 \%$ by weight are miscible with water in every ratio at room temperature. However, upon heating, they may show a phase separation temperature, which depends on structure and concentration, and, as a rule, lies between 45 and $100{ }^{\circ} \mathrm{C}$. In similar studies, the water solubility of PAG was reduced by end-capping the hydroxyl group on the PAG molecular structure with an 
alkyl group (Idoux, McCurry and Amimabhavi 1994). Sheiretov, Glabbeek and Cusano (1996) reported that the approximate saturation limit of polyalkylene glycol is 18,000 ppm and that of polyolester is between 2000 and 4500 ppm. Fukui, Sanechika and Ikeda (2000) remarked that, compared with polyalkylene glycol and polyol ester, moisture absorption of fluorinated alkyl aryl ethers is much slower and reaches a lower equilibrium water content of around $200 \mathrm{ppm}$.

\subsubsection{Hydrolysis}

Tazaki, Konishi and Nagamatsu (1998) noted that moisture enters into the refrigeration and air-conditioning systems during installation or repair and is quite difficult to eliminate by vacuuming. Both polyvinylether and polyolester lubricants are hygroscopic, but polyolesters hydrolyze in the presence of water, while polyvinylethers do not. Sealed tube tests of R-134a/polyolester in the presence of iron, copper, and aluminum and controlled amounts of water indicated that hydrolysis activity tends to increase with high water content or residual carboxylic acid (Jolley 1991). Boyde (1999) looked in detail at the effect of synthetic ester lubricant structure on rate of hydrolysis. He stated that in lubricant service applications, acid-catalysed hydrolysis occurred more frequently than base-catalysed hydrolysis. The hydrolysis reaction rate constants typically showed temperature dependence consistent with an activated process following the Arrhenius equation. The activation energy for hydrolysis of aromatic esters is higher than that for simple polyolesters and diesters, and polyolesters generally had lower rates of 
hydrolysis than analogous diesters. In polyolesters, branching at the 2 or 3 position relative to the ester carbon drastically reduces the rate of hydrolysis compared with analogous linear esters. High acid value and high hydroxyl value in the esters also resulted in faster hydrolysis reactions. The use of acid catcher additives, such as epoxides, could significantly improve the hydrolytic stability of ester lubricants. Similarly, Dick et al. (1996) showed that hindered polyolester is more resistant to hydrolysis than the conventional polyolester and both molecular sieve desiccant and hydrolysis inhibiting chemicals markedly enhance the stability of unadditized and additized lubricants. Epoxy-type acid catchers were shown to be good hydrolysis inhibitors (Iizuka et al. 1996).

\subsubsection{Effect of Water on Tribological Properties of Lubricants}

Lancaster (1990) reviewed the effect of humidity on the friction and wear of metals. In general, under lubricated conditions, water vapor can modify the adsorption of long-chain fatty acids that act as boundary lubricants, thus influencing friction and wear. Water can also affect the chemistry of protective film formation by oxygen. However, depending on the lubricants tested and the conditions of the tests, the effects can be either positive or negative. Drauglis and Snediker (1980) investigated the effects of oxygen and water vapor on the compressive film strength of boundary films on iron substrates and concluded that water is detrimental while oxygen is necessary for the formation of good boundary films from the diester di-2-ethylhexyl sebacate. This conclusion is in agreement with the results of Echin, Novosartov and Kondrat'eva (1983) who stated that the 
hydrolysis of ester-based synthetic oils result in a considerable drop in the level of antiwear and extreme-pressure properties. On the other hand, Helmick and Sherma (1996) studied a commercially available linear perfluoropolyalkylene ether fluid with M50 steel under boundary lubrication, and reported that both friction and wear decrease sharply as humidity increases from 5 to 20 percent, then remain constant as humidity increases to 100 percent. A detailed study by Sheiretov, Glabbeek and Cusano (1996) on the effect of dissolved water on the tribological properties of polyalkylene glycol and polyolester lubricants showed that the lubricant, the contact metals (steel pin on aluminum plate or steel pin on cast iron plate), the atmosphere (whether refrigerant R134a or air), and the moisture content, all have an effect on friction and wear, as shown in Table 3.1. A positive effect corresponds to a decrease in wear with increasing water content and a negative effect corresponds to an increase in wear with increasing water content.

\subsection{WATER AND DESICCANT}

The gas adsorption properties of zeolites are related to the distinctive interaction of the adsorbed molecules with the zeolitic cations in the sterically restricted environment of the tetrahedral framework (Coe 1984; Ruthven 1984). The presence of adsorbed water has a large impact on the arrangement of the cations in the zeolites and on the interactions between the adsorbent and the adsorbed gas (Smith et al. 1967; Dempsey 1969; Breck 1974; Dendooven et al. 1984; Van Dun and Mortier 1988). Kirschhock et al. (2000) studied the arrangements of residual water and alkali-metal cations in Zeolites $\mathrm{Y}$ and $\mathrm{X}$ 
using Rietveld refinement in combination with Fourier analysis of X-ray powder patterns. They discovered that only the cation sodium participates in the interaction with the water molecules, causing the formation of four types of water-sodium structures at low water contents. Heavier alkali-metal ions that are also present affect the formation of these structures by blocking the cation positions for sodium.

\begin{tabular}{||l|l|l|l||}
\hline \hline \multicolumn{3}{||c|}{ TABLE 3.1: SUMMARY OF EXPERIMENTAL RESULTS FROM SHEIRETOV, GLABBEEK AND CUSANO (1996) } \\
\hline \hline Lubricant & Contact metals & Atmosphere & Water Effect on Wear \\
\hline \hline PAG & Steel/Aluminum & R-134a & $\begin{array}{l}\text { Positive from 200 ppm up to 5000 } \\
\text { ppm moisture. After that, no effect }\end{array}$ \\
\hline PAG & Steel/Cast Iron & R-134a & Negative \\
\hline PAG & Steel/Aluminum & Air & Positive \\
\hline PAG & Steel/Cast Iron & Air & Slightly positive \\
\hline \hline POE1 & Steel/Aluminum & R-134a & No effect \\
\hline POE1 & Steel/Cast Iron & R-134a & No effect \\
\hline POE1 & Steel/Aluminum & Air & Positive \\
\hline POE1 & Steel/Cast Iron & Air & Positive \\
\hline \hline $\begin{array}{l}\text { POE2 } \\
\text { higher viscosity) }\end{array}$ & Steel/Aluminum & R-134a & No effect \\
\hline POE2 & Steel/Cast Iron & R-134a & No effect \\
\hline POE2 & Steel/Aluminum & Air & Positive \\
\hline POE2 & Steel/Cast Iron & Air & $\begin{array}{l}\text { Slightly positive (wear is small at } \\
\text { either high or low water content) }\end{array}$ \\
\hline
\end{tabular}

\subsection{WATER AND REFRIGERANT}

The water solubility of hydrochlorofluorocarbons (HCFC) and HFC refrigerants, including R-22, R-123, R-124, R-125, R-134a, R-141b, R-142b, R-152a has been 
reported by McLinden (1989), while Thrasher et al. (1994) studied the moisture solubility in R-123 and R-134a. According to Gehring (1995), water is the single most deleterious contaminant in air-conditioning and refrigeration systems. He discussed sampling and analysis sensitivity to the phase of the sample and showed that higher accuracy can be obtained by using liquid phase samples.

\subsection{PARTITIONING OF WATER BETWEEN REFRIGERANT, LUBRICANT AND DESICCANT}

Cohen and Tucker (1998) stated that, for molecular sieve desiccants, the maximum water capacity is achieved when the refrigerant is excluded from the molecular sieve micropores, because the refrigerant and water molecules compete for the available adsorption sites. They showed that molecular sieve type $3 \mathrm{~A}$ can be modified to exclude refrigerant R-32, and reported the partitioning of water between refrigerants R-410A and $\mathrm{R}-407 \mathrm{C}$ and molecular sieves at $52{ }^{\circ} \mathrm{C}$. When the equilibrium water concentration in the refrigerant is $10 \mathrm{ppm}$, the water capacity of unmodified molecular sieve $3 \mathrm{~A}-6$ is $2.0 \mathrm{~g}$ of water/100 $\mathrm{g}$ of desiccant with R-410A, and 2.9 with R-407C. When the water concentration in the refrigerants is $50 \mathrm{ppm}$, the water capacity of $3 \mathrm{~A}-6$ is 8.7 with R410A and 11.8 with R-407C. In modified molecular sieve 3A-11, the corresponding water capacity at $10 \mathrm{ppm}$ is 8.8 with both R-410A and R-407C, and at $50 \mathrm{ppm}$, the water capacity is 13.9 with both refrigerants. Cohen and Tucker also measured the drydown rate of the molecular sieves in R-407C and R-410A and concluded that both $3 \mathrm{~A}-6$ or $3 \mathrm{~A}-$ 11 would dry the refrigerants very fast in about two hours, and almost completely in 
about six hours. Cavestri and Schafer (1999) studied the equilibrium water capacity of desiccants in mixtures of R-134a and polyolester lubricant. For R-134a containing 2\% by weight mixed acid polyolester lubricant, water loading of 15.5 to $16.5 \%$ on $3 \mathrm{~A}$ molecular sieves provides a $50 \mathrm{ppm}$ equilibrium water, at both $24{ }^{\circ} \mathrm{C}$ and $52{ }^{\circ} \mathrm{C}$. The moisture content of the lubricant is generally below $5 \mathrm{ppm}$. For alumina, under similar concentration of water in the refrigerant and lubricant, water loading of $5.25 \%$ was measured at $24{ }^{\circ} \mathrm{C}$ and $2.5 \%$ at $52{ }^{\circ} \mathrm{C}$. For alumina cores, the water loading was $3 \%$ at 24 ${ }^{\circ} \mathrm{C}$, and $2.5 \%$ at $52{ }^{\circ} \mathrm{C}$. Similar studies were conducted to examine water adsorption by driers in refrigeration systems using R-407C and R-410A with polyolester lubricants (Matsuo, Tagashira and Yoshida 1996).

Rohatgi et al. (2000) studied the distribution of moisture between R-134a, polyalkylene glycol, and desiccant, and concluded that at equilibrium, some moisture from the PAG is redistributed between the refrigerant and the desiccant with the larger fraction going to the desiccant. In addition, the study of moisture dynamics showed that under steady operation, moisture is distributed between R-134a and the PAG lubricant after twenty four hours. The amount of moisture varies according to the total system moisture and, if desiccant is present, on the degree of desiccant saturation. In typical “dry" systems, moisture content of the R-134a is about 25 to $50 \mathrm{ppm}$. In "wet" systems, the moisture level rises to 300 to $400 \mathrm{ppm}$, and with moisture above the saturation level of the desiccant, water content in the R-134a will go to $1500 \mathrm{ppm}$ and above. Goswami et al. (1996) investigated the effect of moisture on the performance of an air-conditioning 
system and determined that approximately 50 to $60 \%$ of the moisture injected into the system remains in the refrigerant and the rest mixes with the compressor oil. Kitamura et al. (1993) conducted a detailed study of the water distribution in an automotive airconditioning system using R-134a. They determined that the saturated water content in the saturated vapor refrigerant at $0{ }^{\circ} \mathrm{C}$ is $350 \mathrm{ppm}$. They concluded that ice will form in the refrigerating cycle at $0{ }^{\circ} \mathrm{C}$ evaporating temperature when the water content in the vapor refrigerant on the low-pressure side is more than $350 \mathrm{ppm}$. In addition, they found that the ratio (") of water content in the vapor over liquid refrigerant in the evaporator is always 0.41 , which is between the " in the equilibrium state (" $=0.18$, following Henry's law) and the " in the state of instantaneous evaporation by the expansion valve $("=$ 0.51). The " value varies depending on the evaporation rate. Moreover, the water content in the liquid refrigerant before the expansion valve is distributed in a fixed ratio to the water content in the vapor refrigerant as well as to the water content in the liquid refrigerant after the expansion valve. With an increase in water content in the refrigerating cycle, the water content in the vapor refrigerant after the expansion valve exceeds the saturated water content, resulting in free water in the refrigerant.

\subsection{RESEARCH NEEDS REGARDING WATER IN REFRIGERANT/LUBRICANT S YSTEMS}

- The mechanism by which water facilitates or hinders lubrication is not known and needs to be studied and characterized. It will be different depending on the chemistry 
of the lubricant, the chemistry and surface of the contact metals, the atmosphere and the temperature around the point of metal to metal contact.

- Detailed studies on the distribution of water in refrigeration and air-conditioning systems, such as the study by Kitamura et al. (1993), would be useful in pinpointing problem areas associated with free water and would help in the formulation and implementation of effective solutions. 


\section{EFFECT OF WATER ON MATERIALS OF CONSTRUCTION IN REFRIGERATION SYSTEMS}

\subsection{EFFECTS ON DESICCANTS}

Cavestri and Schooley (1998) noted that the ability of molecular sieve and alumina desiccants to adsorb hydrochloric acid from R-12 and R-22 refrigerant depends on temperature and water content of the refrigerant. With $3 \mathrm{~A}$ molecular sieves, at less than $10 \mathrm{ppm}$ moisture content, the rate of $\mathrm{HCl}$ adsorption is very slow. The $\mathrm{HCl}$ loading capacity at saturation is at 10.5 to $11 \%$ by weight, both at $24{ }^{\circ} \mathrm{C}$ and $52{ }^{\circ} \mathrm{C}$. When the moisture content is around $60 \mathrm{ppm}$, the rate is about a third faster and the capacity at saturation is $11 \%$ at $24{ }^{\circ} \mathrm{C}$ and $20 \%$ at $52{ }^{\circ} \mathrm{C}$.

\subsection{EFFECTS ON POLYMERS}

The presence of moisture was observed to cause the embrittlement of the polyethylene terephthalate (PET) found in Mylar and Melinex sheet and sleeving insulations (Korleski 1991; Sundaresan and Finkenstadt 1991; Doerr and Waite 1996a; 1996b). Polyester material (used as screen for orifice tube in automotive air-conditioners) is hydrolyzed by humidity, and Hunter et al. (2000) have developed a model to express the rate of polyester hydrolysis in terms of the relative humidity and to connect the degree of hydrolysis to hardness. Kumagai and Yoshimura (2000) reported that absorbed water in cycloaliphatic epoxies (used as electrical insulating material for motors) caused 
hydrolysis of ester linkages leading to decreased tracking resistance or surface resistivity. On the positive side, the presence of water was shown to reduce the effect on fluoroelastomer (FKM) rubbers of amine additives, which can cross-link with the rubbers thus changing their properties (Smith 1960; Dinzburg 1995).

\subsection{EFFECTS ON METALS}

Campbell (1972) described the forms of corrosion encountered in heat exchangers for air conditioning and heating and indicated that corrosion can be avoided by correct choice of alloys, design of components, and equipment operation. The hydrolysis of organic solvents and lubricants or the reactions of refrigerants with water have been shown to cause formicary and large-pit corrosion in copper tubes (Nagata and Kawano 1994; Lenox and Hough 1995), as well as copper plating and sludge formation in refrigeration systems (McGovern 1942). Elliott and Corbett (2001) described formicary or ant-nest corrosion as a particular form of localized corrosion of a submicroscopic nature. The morphology of the corrosion damage within the metal includes a series of minute interconnecting tunnels, starting from the tube surface and propagating rapidly into the tube wall. The corrosion product (copper oxide $\mathrm{Cu}_{2} \mathrm{O}$ ) is usually found in the micro channels. The mechanism of formicary corrosion generally involves the presence of moisture, oxygen and a corrosive agent such as an organic acid. Corrosions of coldrolled steel 1020, copper, aluminum 2S, zinc, and magnesium alloy FS-1 were observed after exposure in R-123 with water for one hundred days (Dupont de Nemours and Company, undated). Sealed tube tests of aluminum, copper and steel specimens in 
R-134a/POE with 50, 250 and 500 ppm water showed that copper plating increases with moisture, but can be partially or fully inhibited with additives depending on the moisture level (Greig, Smith and Swallow 1993). Copper plating was observed with both high moisture level and an additive-free lubricant, but not with the fully formulated polyolester at 300-ppm moisture (Smith, Beggs and Greig 1993).

Herbe and Lundqvist (1997) reviewed the experiences of companies with refrigerant and heat pump equipment that have converted from R-12/mineral oil to R134a/polyolester. They concluded that all the companies surveyed believed that the problems with copper plating and formation of acid could be avoided if residual mineral oil was kept at less than one percent and moisture at less than fifty parts per million. In addition, $75 \%$ of the samples drawn from different converted equipment contained 130 ppm moisture or less.

\subsection{EFFECTS ON S YSTEM PERFORMANCE}

The presence of water in refrigeration systems leads to loss of performance (ICI Americas Incorporated 1994), ice deposition, corrosion of metals, blockage of expansion devices, copper plating, and poor lubrication. Goswami et al. (1996) investigated the effect of moisture on the performance of an air-conditioning system using R-22. They reported that cooling capacity of the system is not affected until about $100 \mathrm{ppm}$ of injected moisture. Beyond that point, the capacity and COP of the system begin to drop with increasing moisture, decreasing by $10-15 \%$ at 1000 ppm injected moisture (around 
$700 \mathrm{ppm}$ moisture in the refrigerant). Moreover, studies of blockage of capillary tubes showed that blockage is low in dry systems, but increases rapidly in the presence of water or when the system is doped with carboxylic acid (Herbe and Lundqvist 1997).

\subsection{RESEARCH NEEDS REGARDING THE EFFECT OF WATER ON MATERIALS OF} CONSTRUCTION

- Although formicary corrosion is a real phenomenon leading to copper tube failures, it is less well known than other forms of corrosion. Elliott and Corbett (2001) have successfully replicated formicary corrosion in the laboratory, but research is still needed to validate the current theories and mechanisms of formicary corrosion. Studies are needed to determine the rate of pit formation and propagation, the conditions of temperature, water content, acid content, and oxygen content needed to initiate the corrosion process. Corrosion inhibitors need to be developed and evaluated.

- The effect of moisture content in the refrigerant/lubricant system on the degradation of polymeric materials such as O-rings and shaft seals needs to be investigated. 


\section{SUMMARY OF INDUSTRY SURVEY}

A survey was developed, with the ARTI 21CR Project Monitoring Subgroup, to determine the refrigeration and air-conditioning industry's concerns about the presence of water in the refrigerant/lubricant systems, as well as the industry's specifications regarding the amount of water allowable in HFC and synthetic lubricants. A sample of the survey is shown in Table 5.1. Twenty-four companies responded to the survey, including four companies producing or servicing equipment in commercial refrigeration, two in residential air-conditioning, and three in commercial air-conditioning. Two companies manufacture flow controls, and two manufacture commercial icemakers. Of the remaining eleven companies, two have products in commercial refrigeration and residential air-conditioning, four in residential and commercial air-conditioning, and five in commercial refrigeration as well as residential and commercial air-conditioning. Table 5.2 shows the type of products covered in the survey and their corresponding capacities, and Table 5.3 shows the different refrigerants and lubricants reported in use in the survey In Figure 5.1 and Table 5.4, the refrigerant/lubricant systems used in the different product lines are compared. R-22/mineral oil is still the refrigerant/lubricant system most in used. In the survey, a larger number of companies reported the use of R-22/mineral oil in residential or commercial air-conditioning than in commercial refrigeration, where more companies reported the use of $\mathrm{R}-134 \mathrm{a} / \mathrm{POE}$ or $\mathrm{R}-404 \mathrm{~A} / \mathrm{POE}$. Fewer companies with products in commercial refrigeration indicated the use of R-410A/POE than in residential or commercial air-conditioning. While more commercial air-conditioners than residential air-conditioners or commercial refrigerators reportedly use R-407C/POE, 
R-22/alkylbenzene is found in all the three types of equipment. A few products also use R134a/PAG, R-410A/POE, R-507A/polyolester, R-507C/PVE, and R-401A/POE. Two commercial refrigeration companies reported using R-22/POE with scroll and screw compressors. The water concentrations specified and expected for different refrigerant/lubricant systems vary depending on the products, their capacities and applications, and also on the companies. In flow controls, the specified values for new field-erected or factory-sealed equipment are less than $50 \mathrm{ppm}$ for HCFC as well as HFC. The expected values after service and re-assembly are also less than $50 \mathrm{ppm}$, but the actual measured values in the field can be as high as $300 \mathrm{ppm}$. In residential air-conditioning, for HCFC refrigerants, the specified water contents ranged from $10 \mathrm{ppm}$ to 1.5 weight percent (reported by one company that did not specify whether the percentage was based on refrigerant, lubricant or refrigerant plus lubricant weight), while the expected water contents are from 10 to $150 \mathrm{ppm}$. For HFC refrigerants, the specified values are from 10 to $50 \mathrm{ppm}$, while the expected values are between 50 and 150 ppm. The measured moisture for both HCFC and HFC is between 13 and 700 ppm. In commercial refrigeration and commercial air-conditioning, the specified values for HCFC and HFC are $100 \mathrm{ppm}$ on the low side or 1.5 weight percent on the high side. The expected values are between 20 and $100 \mathrm{ppm}$, while the measure numbers are as high as $700 \mathrm{ppm}$. Among the problems that would most likely result from the presence of high moisture level in the refrigeration systems, lubricant breakdown is of greatest concern, as shown in Table 5.5. Next in importance is acid formation, followed by compressor failure and expansion valve sticking. Elastomeric seal failure and sticking of suction valve cause fewer concerns. One of 
the respondent engineers noted that, in his opinion, contamination of the POE lubricant with traces of mineral oil is a much larger problem than moisture in the system. Of the twenty-four companies that responded to the survey, seventeen (71\%) use filter driers and six (25\%) employ acid catchers.

\subsection{RESEARCH NEEDS FROM INDUSTRY SURVEY}

- The industry needs to measure and record the water content and total acid number of the lubricant of newly installed systems, as well as operating systems that are shut down for service or repair. The reason for the shutdown and repair needs to be documented. A database can then be established, similar to the one reported by Herbe and Lundqvist (1997), to correlate water content in systems with type of breakdown or problems encountered. Combined with the detailed studies on the distribution of water in refrigeration and airconditioning systems, such as the study by Kitamura et al. (1993), the database would allow the air-conditioning and refrigeration industry to set meaningful limits on the allowable water content in newly installed equipment, either field-erected or factory-sealed. 


\section{TABLE 5.1. CONFIDENTIAL SURVEY: EFFECTS OF WATER IN HVAC S YSTEMS}

1. Please fill in the following table where appropriate:

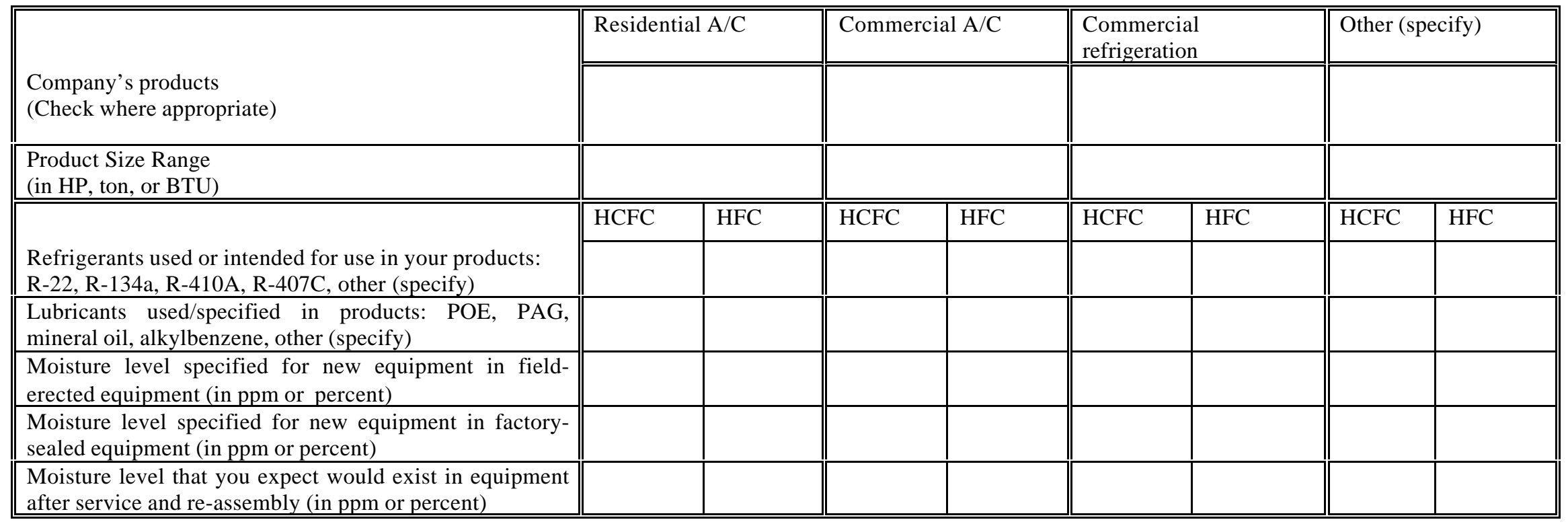

2. In your opinion, high water content in the system would most likely cause (please check all that apply):
( ) compressor failure
( ) elastomeric seal failure
( ) sticking of expansion valve
( ) lubricant breakdown
( ) degradation of motor insulation material
( ) refrigerant breakdown
( ) deterioration of wire coating
( ) ice formation in the evaporator
( ) plugging of suction filter or heat-exchanger (clathrate
( ) acid formation
( ) copper plating
( ) metal corrosion
( ) suction/discharge valve sticking
( ) other
3. Are you using/specifying filter-dryers?
4. Do you use chemicals to catch acids in the lubricant?
5. Have you measured moisture level in the field?:
6. If yes, what range of moisture level have you observed/rs
7. What fraction of your warranty cost has been attributed to moisture in the system? formation)

Comments:

Company's name:

Name of person completing this form (optional):

Title/Position: ( ) engineer, ( ) chemist/scientist, ( ) materials, ( ) manufacturing, ( ) research, ( ) field service, ( ) reliability/quality control 


\begin{tabular}{|c|c|c|}
\hline \multicolumn{3}{|c|}{$\begin{array}{l}\text { TABLE 5.2. PRODUCTS COVERED IN INDUSTRY SURVEY } \\
\end{array}$} \\
\hline Company Number & Products Manufactured & Capacity Range \\
\hline 1 & Flow controls & $1 / 4$ to 400 tons \\
\hline 2 & Flow controls & All system capacities \\
\hline 3 & Commercial refrigeration & $1 / 4$ to $4 \mathrm{HP}$ \\
\hline 4 & Commercial refrigeration & 4,000 to $24,000 \mathrm{BTUH}$ \\
\hline \multirow[t]{3}{*}{5} & Residential air-conditioning & Less than $71 \frac{1}{2}$ tons \\
\hline & Commercial air-conditioning & Less than 350 tons \\
\hline & Commercial refrigeration & Less than 40 tons \\
\hline 6 & Commercial ice-maker & 1,500 to $28,000 \mathrm{BTUH}$ \\
\hline 7 & Residential air-conditioning & 1.5 to 5 tons \\
\hline 8 & Residential air-conditioning & $1 \frac{1}{2}, 2$ and $2 \frac{1}{2}$ tons \\
\hline 9 & Commercial refrigeration (display case) & $1 / 3$ to $1 \frac{1 / 2}{2}$ tons \\
\hline \multirow[t]{3}{*}{10} & Residential air-conditioning & 1 to 5 tons \\
\hline & Commercial air-conditioning & Not specified \\
\hline & Commercial refrigeration & Not specified \\
\hline \multirow[t]{2}{*}{11} & $\begin{array}{l}\text { Residential air-conditioning, including } \\
\text { room air-conditioning }\end{array}$ & Not specified \\
\hline & Commercial air-conditioning & Not specified \\
\hline 12 & Commercial air-conditioning & 12.5 to 2,100 tons \\
\hline 13 & Commercial air-conditioning & 10 to 2,5000 tons \\
\hline \multirow[t]{2}{*}{14} & Residential air-conditioning & $1 \frac{1 / 2}{2}$ to $71 / 2$ tons \\
\hline & Commercial air-conditioning & $1 \frac{1}{2}$ to 40 tons \\
\hline 15 & Commercial refrigeration & $1 / 2$ to 35 tons \\
\hline \multirow[t]{3}{*}{16} & Residential air-conditioning & Not specified \\
\hline & Commercial air-conditioning & Not specified \\
\hline & Commercial refrigeration & Not specified \\
\hline \multirow[t]{3}{*}{17} & Residential air-conditioning & 3 to 7 tons \\
\hline & Commercial air-conditioning & 3 to 48 tons \\
\hline & Commercial refrigeration & 2 ton 30 tons \\
\hline 18 & Commercial ice machines & Not specified \\
\hline 19 & Commercial air-conditioning & 20 to 900 tons \\
\hline \multirow[t]{2}{*}{20} & Commercial air-conditioning & Not specified \\
\hline & Commercial refrigeration & Not specified \\
\hline \multirow[t]{2}{*}{21} & Residential air-conditioning & 1 to 6 tons \\
\hline & Commercial air-conditioning & $1 \frac{1 / 2}{2}$ to 120 tons \\
\hline \multirow[t]{2}{*}{22} & Commercial air-conditioning & 200 to 1,500 tons \\
\hline & Commercial refrigeration & 200 to 1,500 tons \\
\hline \multirow[t]{2}{*}{23} & Residential air-conditioning & 12,000 to $65,000 \mathrm{BTUH}$ \\
\hline & Commercial air-conditioning & 65,000 to $300,000 \mathrm{BTUH}$ \\
\hline \multirow[t]{3}{*}{24} & Residential air-conditioning & Larger than 5,000 BTUH \\
\hline & Commercial air-conditioning & Less than $150,000 \mathrm{BTUH}$ \\
\hline & Commercial refrigeration & 200 to $35,000 \mathrm{BTUH}$ \\
\hline
\end{tabular}




\begin{tabular}{||l|l||}
\hline \multicolumn{2}{|c||}{ TABLE 5.3. REFRIGERANTS AND LUBRICANTS REPORTED IN USE IN SURVEY } \\
\hline Refrigerants & \\
\hline R-22 & Chlorodifluoromethane $\left(\mathrm{CHClF}_{2}\right)$ \\
\hline R-32 & Difluoromethane or methylene chloride $\left(\mathrm{CH}_{2} \mathrm{~F}_{2}\right)$ \\
\hline R-124 & 2-chloro-1,1,1,2-tetrafluoroethane $\left(\mathrm{CHClFCF}_{3}\right)$, a component of R-401A \\
\hline R-125 & Pentafluoroethane $\left(\mathrm{CHF}_{2} \mathrm{CF}_{3}\right)$ \\
\hline $\mathrm{R}-134 \mathrm{a}$ & $1,1,1,2$-tetrafluoroethane $\left(\mathrm{CH}_{2} \mathrm{FCF}_{3}\right)$ \\
\hline R-143a & $1,1,1$-trifluoroethane $\left(\mathrm{CH}_{3} \mathrm{CF}_{3}\right)$ \\
\hline R-152a & 1,1 -difluoroethane $\left(\mathrm{CH}_{3} \mathrm{CHF}_{2}\right)$, a component of R-401A \\
\hline R-401A & Refrigerant blend containing 53\% R-22, 13\% R-152a and 34\% R-124 by weight \\
\hline R-404A & Refrigerant blend containing 44\% R-125, 52\% R-143a and 4\% R-134a by weight \\
\hline R-410A & Refrigerant blend containing $50 \%$ R-32 and 50\% R-125 by weight \\
\hline R-407C & Refrigerant blend containing $23 \%$ R-32, 25\% R-125, and 52\% R-134a by weight \\
\hline R-507 & Refrigerant blend containing 50\% R-125 and 50\% R-143a by weight \\
\hline Lubricants & \\
\hline MO & Mineral oil \\
\hline AB & Alkyl Benzene \\
\hline PAG & Polyalkylene glycol \\
\hline POE & Polyolester \\
\hline PVE & Polyvinyl ether \\
\hline
\end{tabular}

\begin{tabular}{||l|c|c|c||}
\hline \multirow{4}{*}{$\begin{array}{l}\text { Refrigerant/ } \\
\text { Lubricant }\end{array}$} & \multicolumn{3}{|c|}{ TABLE 5.4. REFRIGERANT/LuBRICANT USAGE } \\
\cline { 2 - 4 } & $\begin{array}{c}\text { In commercial } \\
\text { refrigeration }\end{array}$ & $\begin{array}{c}\text { In residential } \\
\text { air-conditioning }\end{array}$ & $\begin{array}{c}\text { In commercial } \\
\text { air-conditioning }\end{array}$ \\
\hline \hline R-22/MO & 5 & 11 & 12 \\
\hline R-22/AB & 4 & 5 & 5 \\
\hline R-22/POE & 2 & 0 & 1 \\
\hline R-134a/POE & 10 & 1 & 2 \\
\hline R-134a/PAG & 2 & 1 & 8 \\
\hline R-410A/POE & 2 & 8 & 1 \\
\hline R-410A/PVE & 0 & 1 & 0 \\
\hline R-401A/POE & 1 & 0 & 2 \\
\hline R-404A/POE & 9 & 1 & 10 \\
\hline R-407C/POE & 2 & 4 & 1 \\
\hline R-407C/PVE & 0 & 1 & 0 \\
\hline R-507A/POE & 2 & 0 & \\
\hline
\end{tabular}




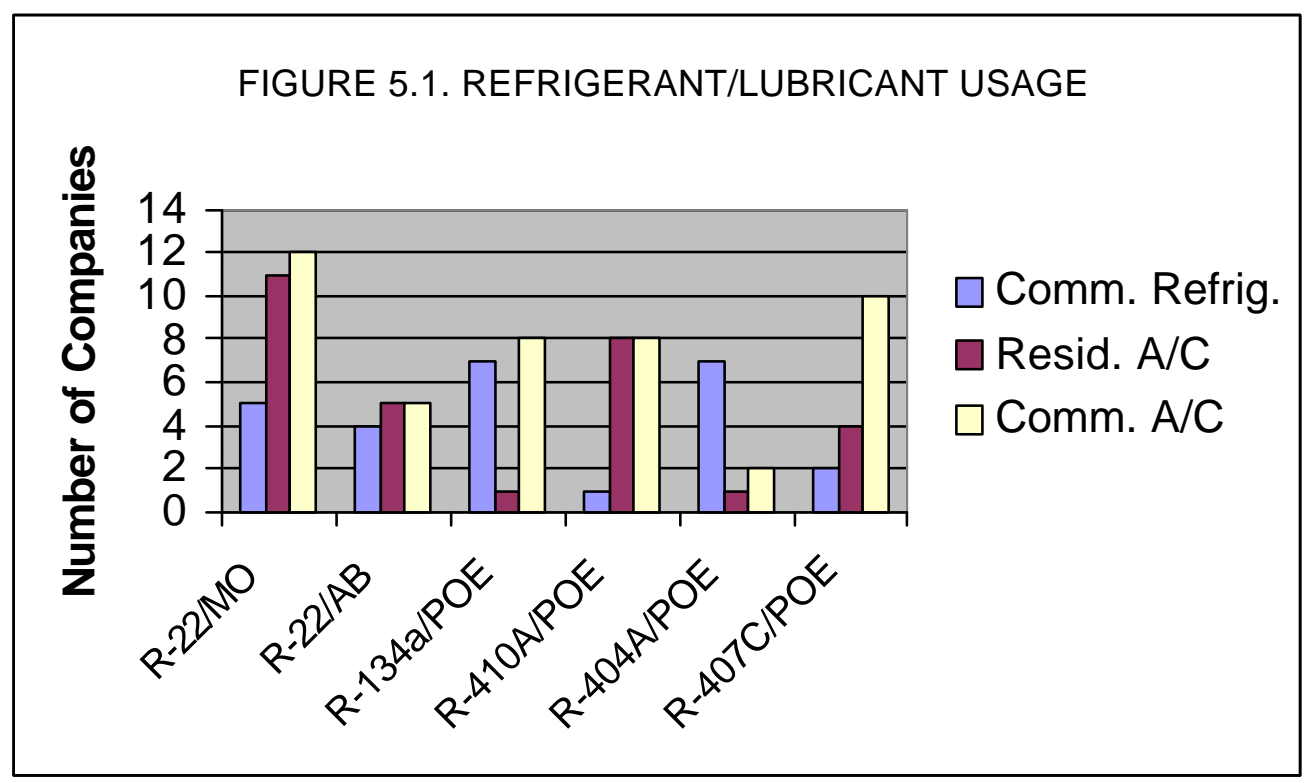

\begin{tabular}{|c|c|c|c|c|c|c|c|c|}
\hline \multirow{3}{*}{\begin{tabular}{|l|} 
Water Content, ppm \\
$*$ Note: different values are \\
reported by different \\
companies \\
\end{tabular}} & \multicolumn{8}{|c|}{ Products } \\
\hline & \multicolumn{2}{|c|}{ Flow controls } & \multicolumn{2}{|c|}{$\begin{array}{l}\text { Commercial } \\
\text { refrigeration }\end{array}$} & \multicolumn{2}{|c|}{$\begin{array}{l}\text { Residential } \\
\text { air-conditioning }\end{array}$} & \multicolumn{2}{|c|}{$\begin{array}{l}\text { Commercial } \\
\text { air-conditioning }\end{array}$} \\
\hline & $\mathrm{HCFC}$ & $\mathrm{HFC}$ & HCFC & HFC & HCFC & HFC & $\mathrm{HCFC}$ & HFC \\
\hline $\begin{array}{l}\text { Limits specified for new } \\
\text { field-erected equipment }\end{array}$ & $<50$ & $<50$ & 100 & $\begin{array}{l}\text { No } \\
\text { spec. }\end{array}$ & 50 & $\begin{array}{l}10 \\
50\end{array}$ & $\begin{array}{r}50 \\
100\end{array}$ & $\begin{array}{r}<10 \\
30 \\
50 \\
100 \\
\end{array}$ \\
\hline $\begin{array}{l}\text { Limits specified for new } \\
\text { factory-sealed } \\
\text { equipment* }\end{array}$ & $<50$ & $<50$ & $\begin{array}{r}100 \\
1.5 \%\end{array}$ & $\begin{array}{r}10 \\
20 \\
100 \\
1.5 \%\end{array}$ & $\begin{array}{r}10 \\
50 \\
1.5 \%\end{array}$ & $\begin{array}{l}10 \\
50\end{array}$ & $\begin{array}{r}10 \\
30 \\
<35 \\
50 \\
100 \\
200 \\
1.5 \%\end{array}$ & $\begin{array}{r}10 \\
30 \\
50 \\
100 \\
1.5 \%\end{array}$ \\
\hline $\begin{array}{l}\text { Limits expected after } \\
\text { service and re-assembly } *\end{array}$ & $\begin{array}{l}<30 \\
<50\end{array}$ & $\begin{array}{l}<45 \\
<50\end{array}$ & $\begin{array}{r}20-25 \\
<30 \\
100\end{array}$ & $\begin{array}{r}20-30 \\
<30 \\
50 \\
100\end{array}$ & $\begin{array}{r}10 \\
25 \\
100 \\
150\end{array}$ & $\begin{array}{r}50 \\
100 \\
150\end{array}$ & $\begin{array}{r}25 \\
<30 \\
60 \\
<100 \\
150 \\
<500\end{array}$ & $\begin{array}{r}<20 \\
<30 \\
50 \\
60 \\
<100 \\
150\end{array}$ \\
\hline $\begin{array}{l}\text { Measured, recorded in } \\
\text { the field }\end{array}$ & & $10-300$ & & $\begin{array}{l}20-155 \\
13-711\end{array}$ & & $\begin{array}{r}250-500 \\
13-711\end{array}$ & & $\begin{array}{r}<50 \\
250-500 \\
200-800 \\
13-711 \\
\end{array}$ \\
\hline
\end{tabular}




\begin{tabular}{|c|c|}
\hline Types of problems & Number of responses \\
\hline Lubricant breakdown & 22 \\
\hline Acid formation & 21 \\
\hline Compressor failure & 19 \\
\hline Copper plating & 16 \\
\hline Expansion valve sticking & 16 \\
\hline Refrigerant breakdown & 13 \\
\hline Degradation of motor insulation material & 13 \\
\hline Metal Corrosion & 12 \\
\hline Ice formation in the evaporator & 11 \\
\hline Deterioration of wire coating & 9 \\
\hline Plugging of suction filter or heat-exchanger (clathrate formation) & 7 \\
\hline Elastomeric seal failure & 6 \\
\hline Suction/discharge valve sticking & 4 \\
\hline Plugging of liquid line filter-drier & 1 \\
\hline
\end{tabular}




\section{CONCLUSIONS}

Since the introduction and use of HFC/synthetic lubricant systems in airconditioning and refrigeration, there has been active research in the area of water content in the new operating fluids and its effect on system components and performance, as evidenced by the number of references cited in this review. However, much remains to be investigated. Based on the literature reviewed, the following research topics are suggested for future investigation, in the order of their importance, practicality and ease of implementation:

1. The air-conditioning and refrigeration industry needs to measure and record the water content and total acid number of the lubricant in newly installed systems as well as operating systems that are shutdown for service or repair. The reason for the shutdown and repair needs to be documented. A database can then be established to correlate water content in systems with type of breakdown or problems encountered. This research project is easy to implement and has practical application, because the database, combined with detailed studies on the distribution of water in refrigeration and airconditioning systems, would help the industry in setting meaningful limits on the allowable water content in newly installed equipment, either field-erected or factorysealed. Such a study can be conducted according to the following tasks:

Task 1: Request participating companies to measure and record the water content and total acid number of the lubricant in newly installed systems. The type of equipment, type of compressor, refrigerant/lubricant systems used need to be documented. 
Task 2: Request participating companies to measure and record the water content and total acid number of the lubricant in operating systems that are shutdown for service or repair. The time in operation before shutdown and the reason for the shutdown and repair, as well as the type of equipment, type of compressor, refrigerant/lubricant systems used need to be documented.

Task 3: Establish a database from which different correlations can be drawn. Such correlations include: water content versus total acid number, water content versus type of breakdown, total acid number versus type of breakdown, change in water content with time, depending on the type of equipment, type of compressor and refrigerant/lubricant system.

2. Along with the database, detailed studies on the distribution of water in refrigeration and air-conditioning systems should be conducted to pinpoint problem areas associated with free water, and to help in the formulation and implementation of effective solutions to these problems. Following the research of Kitamura et al. (1993) for an automotive airconditioning system using R-134a/PAG, the following tasks can be conducted in a detailed study of the distribution of water in a refrigeration or air-conditioning system. The equipment for the various measurements can be of similar design to those described by Kitamura et al.

Task 1: Measure the saturated water content in the gas phase of the refrigerant of interest, if not already available in the literature. 
Task 2: As the amount of water added to the refrigerant circuit is changed, measure the water content in the liquid refrigerant before the expansion valve, and in both the liquid and gas refrigerant after the expansion valve.

Task 3: Compare the water content in the gas refrigerant with the saturated water content of task 1 to assess possible formation of free water during expansion.

Task 4: Measure the water content in the gas refrigerant after the evaporator.

Task 5: Simulate a differential section of the evaporator as described by Kitamura et al., and measure the water content in the liquid and gas refrigerant during evaporation of the liquid refrigerant in a pressure vessel at a constant temperature.

Task 6: Measure the saturated water content in the oil at a temperature corresponding to the low-pressure side of the system.

Task 7: Simulate the water behavior in the evaporator, with the presence of the lubricant, to determine whether free water will separate in the evaporator.

3. Although formicary corrosion is a real phenomenon leading to copper tube failures, it is less well known than other forms of corrosion. Formicary corrosion has been successfully replicated in the laboratory, but research is still needed to validate the current theories and mechanisms for this type of corrosion. Studies are needed to determine the rate of pit formation and propagation, the conditions of temperature, water content, acid content, and oxygen content needed to initiate the corrosion process. Corrosion inhibitors need to be developed and evaluated. 
Elliott and Corbett (2001) were able to successfully replicate formicary corrosion of copper tubes in the presence of a corrosive agent such as formic acid, acetic acid, trichloroethane, and water-based drawing and fitting lubricants. The test copper tubes were placed inside glass test tubes (to avoid direct contact between the copper and the corrosive agent) and the glass tubes were placed in spring clamped Mason jars containing the corrosive agent. Following similar experimental procedures, the following tasks can be conducted to define the rate of formicary pit formation and propagation as functions of acid content, water content, oxygen content and temperature:

Task 1: Develop a test matrix to test the effect of each parameter (water, acid, oxygen concentrations, temperature and exposure time) on the extent of corrosion, separately and in combination with one another.

Task 2: Measure the rate of corrosion, using different analytical techniques such as metal weight loss, x-ray radiography, ultrasonic velocity measurements and sound attenuation measurements, as functions of water, acid, oxygen concentrations and temperature.

Task 3: Determine the minimum value of each parameter for corrosion initiation.

Task 4: Verify that the mechanism for formicary corrosion of copper, as supported by current consensus, involves first an oxidation step, followed by a reaction with a carboxylic acid:

$\left[\mathrm{Cu}^{0} \rightarrow \mathrm{Cu}^{+}+\mathrm{e}^{-}\right]$

$\left[\mathrm{Cu}^{+}+\mathrm{HCOO}^{-} \rightarrow \mathrm{Cu}(\mathrm{CHOO})\right]$ 
In the next step, the copper complex is oxidized. The cupric formate reacts with fresh copper, yielding the unstable cuprous complex. The last two reactions will repeat over and over, resulting in formicary corrosion tunnels.

$\left[\left(4 \mathrm{Cu}(\mathrm{CHOO})+1 / 2 \mathrm{O}_{2} \longrightarrow 2 \mathrm{Cu}(\mathrm{CHOO})_{2}+\mathrm{Cu}_{2} \mathrm{O}\right]\right.$

$\left[\mathrm{Cu}(\mathrm{CHOO})_{2}+\mathrm{Cu}^{0} \rightarrow 2 \mathrm{Cu}(\mathrm{CHOO})\right]$

4. Although studies have been conducted on a number of hydrate formers including hydrofluorocarbon refrigerants, the conditions for formation and decomposition of clathrate hydrates of other alternative refrigerants under consideration for use in refrigeration and air-conditioning systems and water should be determined to avoid possible problems associated with tube plugging. These alternative refrigerants may include R-23, R-41, R-116, R-125, R-143a, and refrigerant blends such as 404A and 507C. A research project, built on the work of Akiya et al. (1999), can be conducted to study the formation and decomposition of clathrate hydrates of R-125, R-143a, and their blends R-404A (44\% R-125, 52\% R-143a, and 4\% R-134a) and R-507C (50\% R-125 and $50 \%$ R-143a). Such a research, in addition to providing additional thermodynamic data, would verify the theory that it is possible to determine the clathrate decomposition conditions of a blend of HFC refrigerants from the data of its individual components. The following tasks would be included in the research program:

Task 1: Obtain the condensation and clathrate formation lines of R-143a. From the intersection of these lines, obtain the critical clathrate formation conditions $T_{c}$ and $\mathrm{P}_{\mathrm{c}}$.

Task 2: Use the thermodynamic data available from Akiya et al. for R-125 or perform additional measurements as desired. 
Task 3: Obtain the condensation line, clathrate formation line, $\mathrm{T}_{\mathrm{c}}$ and $\mathrm{P}_{\mathrm{c}}$ for $\mathrm{R}-$ 404A and R-507C.

Task 4: Plot $\mathrm{T}_{\mathrm{c}}$ on linear scale versus $\mathrm{P}_{\mathrm{c}}$ on logarithmic scale for R-125, R-143a, R-404A and R-507C.

Task 5: Develop correlations between the $\mathrm{T}_{\mathrm{c}}$ and $\mathrm{P}_{\mathrm{c}}$ of the refrigerant blends and those of their individual components.

5. The mechanism by which water facilitates or hinders lubrication is not known and needs to be studied and characterized in order to formulate more effective lubricants and lubricant additives. Sheiretov, Glabbeek and Cusano (1996) indicated that water can oxidize the metal surfaces or it can react with an already existing oxide layer (such as $\left(\mathrm{Al}_{2} \mathrm{O}_{3}\right)$ to form hydroxide (such as aluminum trihydroxide). The oxides or hydroxides provide protective layers against wear of the metal surfaces. Based on the results of Sheiretov, Glabbeek and Cusano, a study to determine the effects of water on lubricity can be developed, involving the following tasks:

Task 1: Expose metal surfaces to different concentrations of water in the presence of lubricant and refrigerant, but in the absence of air, at various exposure time and temperature.

Task 2: Measure the thickness of the oxide layer using Auger Electron Spectroscopy. Task 3: Relate the rate of oxide formation to water concentration and temperature.

Task 4: Expose metal surfaces to different concentrations of air in the presence of lubricant and refrigerant, at various exposure time and temperature.

Task 5: Measure the thickness of the oxide layer formed and relate the rate of oxide formation to the concentration of air and temperature. 
Task 6: Expose the oxide layer obtained in task 4 to different concentrations of water and determine the rate of hydroxide formed as functions of water concentration and temperature.

Task 7: Conduct tribology tests in systems similar to the High-Pressure Tribometer (HPT) described by Sheiretov, Glabbeek and Cusano on the metal surfaces protected by oxide or hydroxide layers obtained in tasks 1 and 6 and determine the rate of wear of the oxide or hydroxide layers.

Task 8: Compare the rates of oxide or hydroxide formation and wear. If the rate of formation were faster than the rate of wear, the presence of water would have a positive effect, resulting in lower wear of the metal surfaces with increasing water concentrations. On the other hand, if the rate of formation were slower than the rate of wear, the presence of water would have a negative effect on lubricity. It should be noted, however, that the type of lubricant and refrigerant used would have the greatest impact on the total lubricity of the system. 


\section{BIBILIOGRAPHY}

Akiya T, Owa M, Nakaiwa M, Tanii T, Nakazawa K, Ando Y. 1991. Novel Cool Storage System Using HCFC-141b Gas Clathrate. Proceedings of the Twenty-sixth Intersociety Energy Conversion Engineering Conference; 1991 Aug 4-9; Boston, MA. New York (NY): American Institute of Chemical Engineers. Volume 6, p 115-9.

Akiya T, Shimazaki T, Oowa M, Nakaiwa M, Nakane T, Hakuta T, Matsuo M, Yoshida M. 1997. Phase Equilibria of Some Alternative Refrigerants Hydrates and their Mixtures Using for Cool Storage Materials. Proceedings of the Thirty-second Intersociety Energy Conversion Engineering Conference; 1997 Jul 27-Aug 1; Honolulu, HI. New York (NY): American Institute of Chemical Engineers. Volume 3, p 1652-5.

Akiya T, Shimazaki T, Oowa M, Matsuo M, Yoshida Y. 1999. Formation Conditions of Clathrates Between HFC Alternative Refrigerants and Water. International Journal of Thermophysics 20(6):1753-63.

Becke P, Kessel D, Rahimian I (Institut fuer Erdoelforschung, Clausthal-Zellerfeld, Germany, FR). 1994. Einfluss fluessiger Kohlenwasserstoffe auf die Zersetzung von Gashydraten (Effects of Liquid Hydrocarbons on the Decomposition of Gas Hydrates). Contract nr BMFT 0326810D, 16 p. In German. Available from: NTIS, Springfield, VA; TIB/A96-03321/XAB

Borah K. 1955. Hermetically Sealed Refrigeration Compressors Lubrication Lubrication Engineering 11:319-22. 
Boyde S. 1999. Hydrolytic Stability of Synthetic Ester Lubricants. Journal of Synthetic Lubrication 16(4):297-312.

Breck DW. 1974. Zeolite Molecular Sieves: Structure, Chemistry, and Use. New York: Wiley. $771 \mathrm{p}$.

Campbell HS. (British Non-Ferrous Metals Research Association, UK). 1972. Experience with Copper Alloys in Heating and Air-conditioning Heat Exchangers. Copper Development Association [CDA] and American Society of Metals [ASM] Conference on Copper; 1972 Oct 16-19; Cleveland, OH. Columbus (OH): Copper Data Center [CDC]. 14 p.

Cavestri RC, Schooley DL. 1998. Test Method for Inorganic Acid Removal Capacity of Desiccants Used in Liquid Line Filter Driers. American Society of Heating, Refrigerating, and Air-conditioning Engineers [ASHRAE] Transactions 104 (Part 1B):1335-40.

Cavestri RC, Schafer WR. 1999. Equilibrium Water Capacity of Desiccants in Mixtures of HFC Refrigerants and Appropriate Lubricants. American Society of Heating, Refrigerating, and Air-conditioning Engineers [ASHRAE] Transactions 105 (Pt 2): $60-5$.

Coe CG. 1990. Gas Separation Technology. In: Vansant EF and Dewolfs R, editors. Proceedings of the International Symposium on Gas Separation Technology: Part 8, 1989 Sep 10-15, Antwerp, Belgium. Amsterdam: Elsevier. 
Cohen AP, Tucker DM. 1998. Drying R-407C and R-410A Refrigerant Blends with Molecular Sieve Desiccants. American Society of Heating, Refrigerating, and Airconditioning Engineers [ASHRAE] Transactions 104 (Part 1A):396-401.

Colle KS, Costello CA, Berluche E, Oelfke RH, Talley LD, inventors; Exxon Production Research Company Houston TX, assignee. 2000 Feb 22. Method for Inhibiting Hydrate Formation. US patent 6,028,233.

Davidson DW. 1973. Clathrate Hydrates. In: Franks F, editor. Water-A Comprehensive Treatise, volume 2, chapter 3. New York-London: Plenum Press. p 115-234.

Dempsey, E. 1969. The Calculation of Madelung Potentials for Faujasite-Type Zeolites. I. Journal of Physical Chemistry 73: 3660-8.

Dendooven E, Mortier WJ, Uytterhoeven JB. 1984. Influence of Temperature and Adsorption on the Cation Distribution in Ca-Y Zeolites. Journal of Physical Chemistry 88:1916-21.

DeVos R, Davis TH. 1997. HFC-134a Qualification, Industry Refrigerator Capillary Data. Proceedings of the International Conference on Ozone Protection Technologies; 1997 Nov 12-13. Baltimore, MD. Arlington (VA): Alliance for Responsible Atmospheric Policy, 10 p.

Dick DL, Vinci JN, Davis KE, Malone GR, Jolley ST. 1996. Polyol Ester Interactions with Additives and Desiccants. Lubrizol Corporation, Wickliffe, OH. 5 p.

Dinzburg BN. 1995. Influence of Lubricant Additives on Rubber Properties in Conditions Similar to the Field. Lubrication Engineering 51(10):796-804. 
Doerr RG, Waite TD. 1996a. Compatibility of Refrigerants and Lubricants with Motor Materials under Retrofit Conditions. Final Report. Washington DC; Department of Energy; 1996 Oct. Report nr DOE/CE/23810-63. 154p. Available from: NTIS, Springfield, VA; DE97001610/XAB.

Doerr RG, Waite TD. 1996b. Compatibility of Refrigerants and Lubricants with Electrical Sheet Insulation Under Retrofit Conditions. In: Braun JE, Groll EA, editors, Proceedings of the 1996 International Refrigeration Conference at Purdue. 1996 Jul 23-26; West Lafayette, IN. West Lafayette (IN): Ray W. Herrick Laboratories, Purdue University. p 175-80.

Dorstewitz F, Mewes D. 1994. The Influence of Heat Transfer on the Formation of Hydrate Layers in Pipes. International Journal of Heat and Mass Transfer 37(14):2131-37.

Drauglis E, Snediker DK (Batelle Columbus Laboratories, Ohio). 1980. An Investigation of the Effects of Oxygen and Water Vapor on the Compressive Film Strength of Boundary Films on Iron Substrates. Final Report 1 Jun 79-30 Nov 80. Washington DC: Air Force Office of Scientific Research; 1980 Dec 31. Report nr TR810036. Contract nr AFOSR-76-3051. 91 p. Available from NTIS, Springfield, VA; ADA094 739/0.

DuPont de Nemours and Company, Incorporated. Undated. Metal Corrosion Tests with HCFC-123 and Distilled Water. Report NIST-10. Wilmington (DE): E.I. DuPont de Nemours and Company, Incorporated. 5 p. 
Echin AI, Novosartov GT, Popova EA. 1981. Hygroscopicity of Synthetic Oils. Chemistry and Technology of Fuels and Oils 17(3-4):198-200.

Echin AI, Novosartov GT, Kondrat'eva TB. 1983. Effect of Water on Lubricating Properties of Synthetic Oils. Chemistry and Technology of Fuels and Oils 19(1-2):80-3.

Elliott P, Corbett RA. 2001. Ant Nest Corrosion-Exploring the Labyrinth. In: Schorr M, editor. Corrosion Reviews 19(1):1-14.

Englezos P. 1992. Incipient Equilibrium Hydrate Formation Condition in Aqueous Polymer Solutions. Chemical Engineering Research \& Design 70:43-7.

Englezos P. 1993. Clathrate Hydrates. Industrial \& Engineering Chemistry Research 32:1251-74.

Ethirajan A, Najafi M. 1993. Mathematical Modeling and Simulation of Latent Heat Cool Storage System. Proceedings of the Twenty-eighth Intersociety Energy Conversion Engineering Conference, 1993 Aug 8-13; Atlanta, GA. Warrendale (PA): [SAE] Society of Automotive Engineers. Volume 2, p 149-54.

Fukui H, Sanechika K, Ikeda M. 2000. Novel Refrigeration Lubricants for Use with HFC Refrigerants. Tribology International 33(7):707-13.

Gehring DG. 1995. How to Determine Concentration of Water in System Refrigerants. American Society of Heating, Refrigerating, and Air-conditioning Engineers [ASHRAE] Journal 37(9):52-5. 
Goswami DY, Mathur GD, Gupta S, Stoff L, Caolacino F. 1996. An Experimental Investigation of the Effect of Moisture on the Performance of an Air-Conditioning System. Proceedings of the $31^{\text {st }}$ Intersociety Energy Conversion Engineering Conference; 1996 Aug 11-16; Washington, DC. Piscataway (NJ): Institute of Electrical and Electronics Engineers [IEEE]. Volume 3, p 2021-26.

Greig BD, Smith AM, Swallow AP. 1993. Household Compressor Manufacturers Adopting HFC Refrigerants; Compressor Lubricants and Manufacturing Fluids Compatibility. Stratospheric Ozone Protection for the 90's. Proceedings of the International CFC and Halon Alternatives Conference; 1993 Oct; Washington, DC. Arlington (VA): Alliance for Responsible CFC Policy, p 100-108.

Gubbins KE. (Cornell University, Ithaca NY). 1993. Molecular Theory and Computer Simulation Studies of Natural and Synthetic Gas Mixtures. Final Report, 1 Jul 9131 Dec 93. Chicago (IL): Gas Research Institute [GRI]. Report nr 940272. Contract nr GRI-5091-260-2255. 134 p. Available from: NTIS, Springfield, VA: PB95-231288/XAB.

Helmick LS, Sharma SK. 1996. Effect of Humidity on Friction and Wear for a Linear Perfluoropolyalkylether Fluid Under Boundary Lubrication Conditions. Lubrication Engineering 52(6):437-42.

Herbe L, Lundqvist P. 1997. CFC and HCFC Refrigerants Retrofit - Experiences and Results. International Journal of Refrigeration 20(1):49-54.

Holder GD, Zetts SP, Pradhan N. 1988. Phase Behavior in Systems Containing Clathrate Hydrates. Review in Chemical Engineering 5(1-4):1-70. 
Hunter LW, White JW, Cohen PH, Biermann PJ. 2000. A Materials Aging Problem in Theory and Practice. Johns Hopkins Applied Technical Digest 21(4):575-81.

Hutter JL, King HE, Lin MY. 2000. Polymeric Hydrate-Inhibitor Adsorption Measured by Neutron Scattering. Macromolecules 33:2670-9.

ICI Americas Incorporated. 1994 Jan. Moisture Content and Emkarate RL Ester Lubricants. Bulletin 62-0170-160. Wilmington (DE): ICI Americas Incorporated. 8 p.

Idoux JP, McCurry CK, Amimabhavi TM. 1994. Densitities, Viscosities, Speeds of Sound, and Water Solubilities of Some Polypropylene Glycol Ether Derivatives in the Temperature Range 273.15-323.15 K. Journal of Chemical and Engineering Data 39:261-265.

Iizuka T, Ishiyama A, Hata H, Sugano T. 1996. Study of Technology for Refrigerant Applications. 1. Materials Compatibility for HCFC-22 Alternative Refrigerants. In: Braun JE, Groll EA, editors, Proceedings of the 1996 International Refrigeration Conference at Purdue, 1996 Jul 23-26; West Lafayette, IN. West Lafayette (IN): Ray W. Herrick Laboratories, Purdue University. p 515-20.

Jolley ST. 1991. The Performance of Synthetic Ester Lubricants in Mobile AirConditioning Systems. Unpublished presentation at the Society of Automotive Engineers [SAE] Passenger Car Meeting and Exposition; 1991 Sep 16-19; Nashville, TN. 14 p. 1996 Jul 23-26; West Lafayette, IN. West Lafayette (IN): Purdue University. p 175-80. Available from: Air-conditioning and Refrigeration 
Technology Institute [ARTI] Refrigerant Database, www.arti-21cr.org/db, RDB2C07.

Jolley ST, Davis KE, Malone GR. 1996. The Effect of Desiccants in HFC Refrigeration Systems Using Ester Lubricants. Lubrizol Corporation, Wickliffe, OH. 12 p.

Kato M, Iida T, Mori YH. 2000. Drop Formation Behavior of a Hydrate-forming Liquid in a Water Stream. Journal of Fluid Mechanics 414:357-78.

King HE Jr., Hutter JL, Lin MY, Sun T. 2000. Polymer Conformations of Gas-hydrate Kinetic Inhibitors: A Small-angle Neutron Scattering Study. Journal of Chemical Physics 112(5):2523-32.

Kirschhock C, Fuess H. 1996. m-Dinitrobenzene in Zeolite NaY: Four Different Arrangements. Zeolites 17:381-8.

Kirschhock C, Hunger B, Martens J, Jacobs PA. 2000. Localization of Residual Water in Alkali-Metal Cation-Exchanged X and Y Type Zeolites. Journal of Physical Chemistry 104:439-48.

Kitamura K, Ohara T, Honda S, Sakakibara H. 1993. A New Refrigerant Drying Method in an Automotive Air-Conditioning System Using R-134a. American Society of Heating, Refrigerating, and Air-conditioning Engineers [ASHRAE] Transactions: Research 99(pt 1):361-7.

Klug P, Holtrup F, inventors; Clariant GmbH Frankfurt DEX, assignee. 2001 Jan 23. Additives for Inhibiting Gas Hydrate Formation. US patent 6,177,497. 
Koga K, Tanaka H, Nakanishi K. 1994. On the Stability of Clathrate Hydrates Encaging Polar Guest Molecules: Contrast in the Hydrogen Bonds of Methylamine and Methanol Hydrates. Molecular Simulation 12(3-6):241-52.

Korleski JE. 1991. The Performance of PET Motor Insulation in CFC-free Refrigerant Systems [abstract]. In: 1991 Proceedings of the $20^{\text {th }}$ Electrical Electronics Insulation Conference; 1991 Oct 7-10; Boston, MA. Piscataway (NJ): Institute of Electrical and Electronics Engineers [IEEE]. p 190.

Kumagai S, Yoshimura N. 2000. Impacts of Thermal Aging and Water Absorption on the Surface Electrical and Chemical Properties of Cycloaliphatic Epoxy Resin. Institute of Electrical and Electronics Engineers [IEEE] Transactions on Dielectrics and Electrical Insulation 7(3):424-31.

Kussi S. 1985. Chemical, Physical and Technological Properties of Polyethers as Synthetic Lubricants. Journal of Synthetic Lubrication 2(1):63-84.

Lancaster JK. 1990. A Review of the Influence of Environmental Humidity and Water on Friction, Lubrication and Wear. Tribology International 23(6):371-389.

Lederhos JP, Long JP, Sum A, Christiansen RL, Sloan Jr. ED. 1996. Effective Kinetic Inhibitors for Natural Gas Hydrates. Chemical Engineering Science 51:1221.

Lenox RS, Hough PA. 1995. Minimizing Corrosion of Copper Tubing Used in Refrigeration Systems. American Society of Heating, Refrigerating, and Airconditioning Engineers [ASHRAE] Journal 37:50-6.

Matsuo M, Tagashira M., Yoshida Y. 1996. The Characteristics of Water Adsorption by Drier in Refrigeration Cycle. Paper D 203. Proceedings of the Seventeenth Japan 
Symposium on Thermophysical Properties. p 227-230. In Japanese with English abstract. Available from: Air-conditioning and Refrigeration Technology Institute [ARTI] Refrigerant Database, www.arti-21cr.org/db, RDBA218.

McGovern EW. 1942. Chemical Effects in Refrigerating Systems. Refrigerating Engineering 43(5):276-9.

McLinden MO. 1989. Physical Properties of Alternatives to the Fully Halogenated Chlorofluorocarbons. International Journal of Thermophysics 10:563-76.

Mori YH. 1996. Boiling of Superheated Fluorocarbon Drops in Water. Effect of Clathrate-hydrate Shells Encapsulating Drops. Physics of Fluids 8(9):2558-60.

Nagata K, Kawano K. 1994. Case Study on the Failure of Copper Air Conditioner Tubes. Shindo Gijutsu Kenkukaishi (Journal of the Japan Copper and Brass Research Association) 33:7-16.

Namba T, Fujii Y, Saeki T, Kobayashi H, inventors; Nippon Shokubai Co., Ltd., Osaka, Japan, assignee. 2001 May 15. Clathrate Hydrate Inhibitor and Method of Inhibiting the Formation of Clathrate Hydrates Using It. US patent 6,232,273.

Nippon Reito Kyokai [Japanese Association of Refrigeration, JAR]. 1981 Thermophysical Properties of Refrigerants (R-12, Dichlorodifluoromethane). Tokyo, Japan. (with errata dated 1986). 160p.

Notz PK, Bumgardner SB, Schaneman BD, Todd JL. 1996. Application of Kinetic Inhibitors to Gas Hydrate Problems. Society of Petroleum Engineers [SPE]: Production \& Facilities 11(4):256-60. 
Ohmura R, Kashiwazaki S, Mori YH. 2000. Measurements of Clathrate-Hydrate Film Thickness Using Laser Interferometry. Journal of Crystal Growth 218:372-380.

Ohmura R, Shigetomi T, Mori YH. 1999. Formation, Growth and Dissociation of Clathrate Hydrate Crystals in Liquid Water in Contact with a Hydrophobic Hydrate-forming Liquid. Journal of Crystal Growth 196:164-173.

Oowa M, Nakaiwa M, Akiya Y, Fukuura H, Suzuki K, Ohsuka M. 1990. Formation of CFC Alternative R-134a Gas Hydrate. Proceedings of the Twenty Fifth Intersociety Energy Conversion Engineering Conference; 1990 Aug 12-17; Reno, NV. Piscataway (NJ): Institute of Electrical and Electronics Engineers [IEEE]. Volume 4, p 269-74.

Pakulski, MK, inventor; BJ Services Company, Houston, TX, assignee. 1998 Apr 21. Method for Controlling Gas Hydrates in Fluid Mixtures. US patent 5,741,758.0.

Rabeony M, Peiffer DG, Costello CA, Wright PJ, Colle KS, Talley LD, inventors; Exxon Production Research Company, Houston, TX, assignee. 1998 Nov 24. Surface Active Agents as Gas Hydrate Inhibitors. US patent 5,841,010.

Rohatgi NDT, Henderson DR, Amin JJ, Jan Xu, Karas LC. 2000. Effect of Desiccant on the Stability of Automotive Air Conditioning Systems. Paper 2000-01-0983. Society of Automotive Engineers [SAE] 2000 World Congress, Detroit, Michigan. $6 \mathrm{p}$.

Ruthven DM. 1984. Principles of Adsorption and Adsorption Processes. New York: Wiley. 433 p. 
Sloan ED, Subramanian S, Matthews PN, Lederhos JP, Khokhar AA. 1998. Quantifying Hydrate Formation and Kinetic Inhibition. Industrial \& Engineering Chemistry Research 37:3124-32.

Smith TL. 1960. Mechanism of Amine Crosslinking of Fluoroelastomers. Journal of Polymer Science 45:405-13.

Smith JV, Bennett JM, Flanigen EM. 1967. Dehydrted Lanthanum-exchanged Type Y Zeolite. Nature 215:241-4.

Smith AM, Beggs MC, Greig BD. 1993. Experience of Retrofitting Automotive AirConditioning from CFC-12 to HFC-134a. Paper 930292. Society of Automotive Engineers [SAE] International Congress and Exposition; 1993 Mar 1-5; Detroit, MI. Warrendale (PA): Society of Automotive Engineers. 8 p.

Sugaya M, Mori YH. 1996. Behavior of Clathrate Hydrate Formation at the Boundary of Liquid Water and a Fluorocarbon in Liquid or Vapor State. Chemical Engineering Science 51(13): 3505-17

Sundaresan SG, Finkenstadt WR. 1991. Degradation of Polyethylene Terephthalate Films in the Presence of Lubricants for HFC-134a: A Critical Issue for Hermetic Motor Insulation Systems. Revue Internationale du Froid 14:317-20.

Tanii T, Minemoto M, Nakazawa K, Ando Y. 1997. Study on a Cool Storage System Using HCFC (Hydro-chloro-fluoro-carbon)-141b $\left(\mathrm{CCbFCH}_{3}\right)$ (1,1-dichloro-1fluoro-ethane) Clathrate. The Canadian Journal of Chemical Engineering 75:353-61 
Tazaki T, Konishi T, Nagamatsu N. 1998. Development of Polyvinylether Refrigeration Oil for Hydrofluorocarbon Air-Conditioning Systems. American Society of Heating, Refrigerating and Air-conditioning Engineers [ASHRAE] Transactions 104 (pt 1B):1341-6.

Thrasher JS, Timkovich R, Kumar HPS, Hathcock SL. 1994. Moisture Solubility in Refrigerant 123 and Refrigerant 134a. Paper 3770 (602-RP), American Society of Heating Refrigerating, and Air-conditioning Engineers [ASHRAE] Transaction; 100 (1):346-57

Sheiretov T, Glabbeek WV, Cusano C. 1996. The Effect of Disssolved Water on the Tribological Properties of Polyalkylene Glycol and Polyolester Lubricants. Lubrication Engineering 52(6):463-73.

Van Dun JJ, Mortier WJ. 1988. Temperature Dependent Cation Distribution in Zeolites. 1. A Statistical Thermodynamical Model. Journal of Physical Chemistry 92:6740-6.

Walker WO, Rosen S, Levy SL. 1962. Stability of Mixtures of Refrigerants and Refrigerating Oils. American Society of Heating, Refrigerating, and Airconditioning Engineers [ASHRAE] Journal 4(8):59-72. 